\title{
Is Globalisation Taking us for a Ride?
}

\author{
Miroslav N. Jovanović \\ University of Geneva
}

\begin{abstract}
Globalisation is one of the great economic and political stories of our times. It was supposed to be one of the great new ideas. The current wave of globalisation is just a subset of huge structural changes that are the outcome of the Schumpeterian evolution in technology, and spatial intensity and scope of interactions between many actors at all levels of the economy. There is, however, a lot of confusion and disagreement in discussions since the process of globalisation means different things to different people. If globalisation is the outcome of the behaviour of transnational corporations, then this process is made possible by new technologies that permit spatial fragmentation of production and value chain, as well as reduction in the cost of transport and communications. The power of firms is increased to the detriment of the power of the state. Even so, governments supported by the general public and non-governmental organisations are able (but not always willing) to cap the globalisation process. Globalisation brings many amenities to society. There were once hopes that globalisation would benefit everyone. As time passes, globalisation's downside becomes more and more apparent. If the goal of globalisation is to introduce and force the same standards everywhere and for everyone (including in the way in which people think), then there may be no room for differences.
\end{abstract}

- JEL Classification: F23, F15

\footnotetext{
*Corresponding address: Miroslav N. Jovanović UN Economic Commission for Europe (UNECE), Transport Division, Palais des Nations, 1211 Geneva 10, Switzerland, Tel: +41 22917 2493, e-mail: miroslav.jovanovic@unece.org

This article is based on a chapter in the International Handbook on the Economics of Integration (ed. M. Jovanović) Cheltenham: Edward Elgar (2011). I have benefited from discussions with many friends and colleagues, but I owe a special debt of gratitude to Grazia Ietto-Gillies, Isidora Ljumović, Richard Pomfret, Alan Rugman and unanimous referees. The views expressed are my own and do not necessarily reflect the position of the organisations for which I work.

(C2010-Center for International Economics, Sejong Institution, Sejong University, All Rights Reserved.
} 
- Key Words: Globalisation, Fragmentation, TNCs, FDI, Technology, Integration

\section{Introduction}

The purpose of this article is to contribute to the discussion about globalisation, which is one of the great economic and political stories of our times. It was also supposed to be one of the big new ideas in the 'post-modern society'. Globalisation put a new emphasis on spatial economics and the importance of economic geography because of the spatial spread of certain economic activities in some geographical locations and the contraction of certain business in others.

There were once hopes that globalisation would benefit everyone everywhere. As time passes by, globalisation's downside becomes more and more apparent. There was an expectation, fuelled by the neoclassical equilibrium theory, that money would go to the developing countries, as the rate of return was supposedly higher there (because of its relative scarcity) than is the case in the developed world. What we have been witnessing is the flow in the opposite direction. Joseph Stiglitz wrote that 'Globalisation seems to have unified so much of the world against it, perhaps because there appear to be so many losers and so few winners... Well-managed globalisation can make everyone, or at least most, better off. This has not happened.' ${ }^{1}$ The current wave of globalisation is on such an unmatched scale that it has involved more countries and people than ever before. For instance, many tens of millions of Chinese got jobs because of globalisation of production, but this did not trickle down fully to their well-being as the distribution of income remained highly concentrated.

This article is structured as follows. Section II provides the background for our discussion. Global institutions, the backlash against them and transnational corporations (TNCs) are introduced in section III. Section IV tries to find definition for the globalisation process. Arguments for and against globalisation are covered in section V. The impact of global standards is considered in section VI. Section VII compares old and new waves of globalisation and finds many similarities between them, but also important differences. The corporate social responsibility, evaluated in section VIII, sheds light on corporate 'philanthropy'. A selection of other dimensions of globalisation is discussed in section VIIII, which is followed by the conclusions.

\footnotetext{
'J. Stiglitz, 'We have become rich countries of poor people', Financial Times, 7 September 2006.
} 


\section{Background}

Liberalisation in the national and international economy is a policy choice of governments. It is linked with the privatisation and downsizing of public sector activities and the expansion of private sector business. General liberalisation, especially in trade and investment, is expected to increase economic efficiency, while preferential deals in trade have, in general, ambiguous total welfare effects (Viner-Lipsey welfare ambiguity).

Globalisation of the economy and production is a fact. This immaterial and impersonal force and process is the outcome of the behaviour of firms (TNCs); their organisation; takeovers; changing technology that allowed fragmentation of the value chain and spatial spread of production and distribution (unbundling of production chains and re-linking of tasks and skills); control and finance; standards; as well as economies of scale. In part, it is also the consequence of a change in the behaviour of consumers (fickleness and declining loyalty ${ }^{2}$ to certain national producers and products) ${ }^{3}$ and liberalisation of national and international economies for trade, production and finance. Because globalisation is immaterial and impersonal, it may not be located in a defined geographical space, it cannot be taxed or prosecuted, but it governs to an extent the lives of people that it touches. Globalisation seems to be something like an emperor without an empire. The current wave of globalisation is just a subset of huge structural changes that are the outcome of the Schumpeterian evolution in technology and spatial intensity and scope of interactions between many actors at all levels of the economy.

Financial scandals such as the ones linked with Enron and WorldCom (both in 2002) created a public outcry against deregulation. This was reinforced in the aftermath of the global credit crunch of 2007-08 which was based on the deregulated American financial alchemy. The idea that the firms are best policed by themselves, and that markets are always self-correcting is shaken. In fact, following the global credit crunch, the free market economy and lax regulation

\footnotetext{
${ }^{2}$ The chairman of Mercedes Benz remarked in an interview in 2004 that the company manufactures cars in China and Eastern Europe not only because of low costs of production and growing local markets, but also because clients do not care any more about where the cars are made (Kim, 2008, p. 235).

${ }^{3}$ One should not accord an absolute value to the decline of consumer loyalty to local brands. Regional rather than 'global' strategies in certain food and healthcare products may offer a superior business outcome. However, there was a certain 'global success' by, for example, Coca-Cola, which succeeded in replacing a part of the consumption of milk and healthy natural fruit juices with an artificial sweet liquid that has a questionable impact on health and weight.
} 
(zero government plus the constable) failed. ${ }^{4}$ The Western world's smug reputation and credibility for competence in running a market economy was globally devastated. 'Globalisation' based on such principles fell into deep trouble. Many invoke the merits of regulation. Governments stepped in forcefully (at the expense of taxpayers) to replace a number of market functions. The danger now is that the authorities may over-regulate the economy which may choke entrepreneurship (risk taking) that may deter innovation. The proper balance between a full freedom and 'policing' is hard to strike. None the less, it ought to be reached in a democratic process which respects private property rights in the emerging Capitalism version 2.0. Keeping markets global and open demands international cooperation, not only in regulation, but also in coordination in macroeconomic policies.

As a process primarily driven by technology and actions of TNCs (power is shifted from states to firms) ${ }^{5}$, globalisation lacks two important components: transparency and accountability. Many are suspicious about corporations and their increasing power over everybody's life and behaviour. An obvious example is the influence of large pharmaceutical TNCs on governments and the World Trade Organization (WTO). One case in question relates to trade-related intellectual property rights.

Banks and big car making TNCs were able to muster enormous government subsidies throughout the world following the global credit crunch of 2007-08. ${ }^{6}$ Ultimately, domestic taxpayers will have to pay for this subsidy spree even though they were not asked anything about it. If a lack of total demand is causing

\footnotetext{
${ }^{4}$ The deteriorating global economy (as the consequence of the global credit crunch) means that 'financial institutions now face total losses of $\$ 4,100 \mathrm{bn}$ on loans and other assets' (O'Connor, 'IMF puts financial losses at \$4,100bn', Financial Times, 21 April 2009). These 'writedowns estimated by the IMF are equal to 37 years of official development assistance at its 2008 level' (M. Wolf, 'Fixing bankrupt systems is just the beginning', Financial Times, 28 April 2009). Is this hefty loss of a sufficient volume to prove that the too liberal markets may not be self-policing?

${ }^{5}$ The army contingents, then the church, then the state once determined our life and order in society, and now it is large corporations. (The church continues to be against laws that allow Sunday shopping and work in order to protect its attendance figures.) Governments court firms (TNCs) to relocate businesses inside the confines of their control. Critics say that the protection of the vulnerable in society or safeguarding of the environment is weakened, even that it is left to the mercy of big businesses. This may be the case in certain lines of production, but it all depends on specific circumstances. In some cases the regulatory framework facing TNCs was strengthened, while in others it was loosened.

${ }^{6}$ For instance, the European Commission approved public aid to the Royal Bank of Scotland by the British government. "We're talking about a very, very large amount of public aid here, between $£ 60-100$ billion ( $€ 67-111 \mathrm{bn}$ )," said commission competition spokesman Jonathan Todd while announcing the decision to journalists. "This is the largest amount of state aid ever received in the EU's history" (A. Willis, 'EU approves largest state aid plan in union's history', EUObserver, 14 December 2009).
} 
problems, why do the authorities not raise demand throughout the economy and let consumers decide what they want to buy? A rhetorical question is: why should the taxpayers be forced to subsidise (only) the industry that makes cars that they do not want to buy and drive? Is the political power of this industry so overwhelming?

It is a disaster to the depositors and employees (and for the country) if a bank fails. Particularly a big bank. However, if it is badly run, then it ought to fail. That is how a market economy operates. The pressure is on the government to come to the rescue of such a bank, and pour taxpayers' resources into a failing business. The question for the policy makers is the following: what is worse for the national economy and its future? Is it the disaster of a failing bank at home or another disaster of a government that is plagued with making subsidies to failed businesses, leaving it with less financial means to assist those that may have a much brighter and promising future?

Subsidising industries that have the smartest and loudest lobbies has often been wasteful and unfair. The underlying 'intellectual' idea and hope for these subsidies is that the world would return to the situation as it was before the global credit crunch and crisis. However, evolutionary economics teaches us that this will not be the case. Saving jobs in inefficient firms today, destroys jobs with more competent and promising employers.

In America, the taxpayers are concerned that the government broke the American social contract for the benefit of big corporations by requiring taxpayers to provide finance and to bear the risks (privatisation of benefits and socialisation of risk). The American social contract was in general (until the credit crunch of 2007-08) that firms and individuals would have full freedom to succeed or fail without public assistance. Full freedom ideology contributed to the removal of limits that functionally separated financial institutions during the last decades of the $20^{\text {th }}$ century. These huge financial institutions were charged with infighting among senior managers and their groups, their clashing interests and their business cultures. None the less, their command of huge resources provided these financial monsters with excessive economic, financial and political clout. In the name of free markets, these man-made behemoths threaten to demolish the very spirit of free markets. This may not be easily and painlessly un-done in the near future. The governments in many countries, particularly in the United States (US), were propping up these giants with public money. In any case, budget deficits are looming globally and the world of higher taxes and global tax policing is approaching. 
The process of globalisation deals with the change in the geography of (fragmented and integrated international) production and consumption as it reduces the importance of spatial proximity to inputs or markets for a firm's output. It widens boundaries and deepens space for the geographical location of production and consumption because of the declining costs of getting goods and services to the market. A rapid expansion of foreign direct investment (FDI) is the key component of this process. Capital market liberalisation and increased capital mobility have radically reduced the influence of governments in the monetary sphere. However, governments have gained increased control in other areas. For example, computers and information technology have greatly increased potential for data collection and processing, and consequently control over firms and citizens, which is relevant for tax and other purposes.

It is well known that roughly a quarter of trade in the world takes place between countries that share common borders. Trade costs and global trade are still affected by spatial distance to a noted degree. Hummels (2006, p. 19) argued:

Distance impedes trade to a surprising extent. Roughly half of world trade takes place between countries located within 3000 kilometres of each other... typical estimates suggesting that doubling distances halves trade. ... costs are substantially rising in distance, but this effect has diminished over time. ${ }^{7}$

Porter (1994) succinctly explained the role of location in global competition. First he mentioned that for the most part earlier research on 'locational choices were more of an operational detail than strategic' (p. 35); that there is a weakening link between location and input cost minimisation; and that 'in a world of global competition, ... location is no longer relevant' (p. 35). As a reaction to such a state of affairs, Porter immediately added that 'this line of reasoning about location, however, does not square with the empirical evidence' (p. 35). A striking and persistent difference in the national economic performance or the operation of regions, even cities, indicates the importance of location. Another sign of the significance of location is spatial concentration of firms. Even though TNCs fragment the production value chain and disperse their business worldwide because of new technologies, falling communication and transport costs, their most sophisticated activities are usually located and

\footnotetext{
${ }^{7}$ Even though road haulage is not considered in his study, it is interesting to note that in the 1970-99 period the value of trade in all products increased 18 times, while the tonnage transported by sea and air combined more than doubled (Hummels, 2006, pp. 21-22). Hence international trade became on average 'lighter' weight wise, while transported goods have become more expensive.
} 
concentrated in their home country where they may benefit from the existing pool of specialised services.

\section{Global Institutions}

Regional integration groups are continuing to increase importance in the world economy (Fiorentino, 2011). This was exemplified in the inability of 135 member countries of the WTO to agree even on the agenda for the 'Millennium Round' of global trade negotiations that took place in Seattle in 1999. Well-organised, vociferous and strong worldwide protests by environmentalists, farmers, enemies of genetically modified food and big business, human rights activists, labour unions, anti-capitalists, those who are in favour of a more balanced distribution of income between and within countries, as well as animal rights activists, exacerbated the problems of that meeting and many others that followed throughout the world.

Although international trade negotiations have taken place in the penumbra of obscurity since the Second World War, this will not be the case after Seattle. There are deep divisions about the nature and extent of globalisation as shaped and conducted by the perceived instruments of global control such as the WTO, the World Bank, the International Monetary Fund (IMF) and TNCs. Therefore, the creation of integrated global economic policies is likely to be a very hard task for quite some time to come. It seems that the bilateral and regional approach to economic problems will call the tune, at least in the medium term. This is obvious following the indefinite suspension of negotiations under the auspices of the WTO Doha Round from July 2006. Hence, in the new situation, special, strong and sometimes particularly dangerous interests may be given almost free rein. Gone are the days when liberal (free) trade on a multilateral and global basis was the principal game in town. Even the free trading minded British have started to worry about the wisdom of reliance on free markets for the supply of energy and food.

The existence and importance of global international institutions such as the WTO, the World Bank and the IMF is not self-evident. The liberal phase of the world economy in the 1850-1914 period operated smoothly without comparable institutions. The only global institution for centuries was the church. The prevailing gold standard was not created by an international agreement. It evolved spontaneously because of conveniences in practice, experience and network effects. Why were these global institutions created after the Second World War? The 
answer to this question relies on four overlapping issues (Wolf, 2004, pp. 73-74):

- Logically: struggle for dominance can lead to war. An international regime may be a solution to this problem.

- Historically: as the dominant power after the Second World War, the US preferred an articulated constitutional order. The US had a passion at that time for formal international institutions. Britain, however, preferred informal agreements during its period of hegemony prior to the First World War.

- Politically: it may be hard to convince the public of the virtues of unilateral action in international trade and investment. This may look to many people like unilateral disarmament; hence an international framework may be necessary.

- Economically: if an economic action is simultaneous among countries, the gains are multiplied. An international legal framework may provide greater security for all. The biggest gainers are the countries that previously had a poor reputation.

In spite of their high profile, many global institutions are losing influence and relevance. Some of them may be losing even their purpose. Asian countries are dissatisfied with the IMF's voting structure which favours Europe and the US without taking into account huge and growing reserves in Asia. The Latin American countries of Argentina and Brazil have been among the biggest clients of the Fund. These two countries repaid IMF loans as soon as possible and in advance in order to avoid the disastrous policies introduced by the IMF's conditionality. In addition, Horst Köhler and Rodrigo Rato, the last two heads of the IMF, each resigned prematurely. That has never been a good sign. ${ }^{8}$ Dominique Strauss-Kahn, the current head of the IMF, signalled that he would step down early from this

\footnotetext{
${ }^{8}$ The usual global policy advice (remove all market imperfections) of the IMF falls into the trap of onesize-fits-all advice at all times. Context-specific issues are neglected and the policy interventions often result in economic disasters, as was the case with the IMF interventions in some unlucky Latin American countries in the 1980s. The policy advice was not based on what actually works in practice, but rather what the IMF officials would like to see operate in line with the neoclassical theory. 'The standard IMF procedure before visiting a client country is to write a draft report first. The visit is only intended to fine-tune the report and its recommendations, and to catch any glaring mistakes' (Stiglitz, 2002, p. 47). Different national institutions and their capabilities, various national levels of development and established specialisations were neglected by the Fund (not to mention social fairness). It was simply assumed that the private sector would swiftly replace almost any government activity. 'The IMF simply assumed that markets arise quickly to meet every need, when in fact, many government activities arise because markets have failed to provide essential services' (Stiglitz, 2002, p. 55; emphasis original). It has to be recognised that the neoclassical market equilibrium forces do operate in practice (to an extent), however this process is somehow selective and sometimes quite slow. As such it may not always be politically acceptable. Hence, intervention may be necessary and welcome.
} 
prestigious and powerful position. ${ }^{9}$ The global credit crunch of 2007-08 and its aftermath gave a new lease of life to the IMF, as almost nobody else was able and willing to provide finance to the countries that were virtually broke. ${ }^{10}$ Financial markets were replacing the World Bank in project financing. The WTO is on a margin because of a stall in the Doha Round trade liberalisation negotiations and many have a problem remembering why the International Labour Organisation (ILO) exists at all.

A changing US attitude towards international organisations may be seen from the following example:

At the San Francisco conference in 1945, Harry Truman stated as US policy that 'We have all to recognise, no matter how great our strength, that we must deny ourselves the licence to do always as we please.' By contrast, a central theme of George W. Bush's re-election campaign in 2004 was that the US would not ask for a 'permission slip' before taking decisions (Ahearne et al., 2006, p. 10, italics original).

Certain global institutions might have exhausted their original reasons for existence, other institutions might have been supplanted by the private sector, the motives for yet other organisations have changed, but the overall basis for the existence of the United Nations (UN) is more relevant than ever. Without the UN, the ideal of a world based on rules would disappear.

The rapid international expansion of TNCs made them the most visible feature of globalisation. Being foreign, sometimes making visible and highly publicised mistakes and often being big in a small country, TNCs are easy targets for nongovernmental organisations (NGOs) that can run successful campaigns to disgrace a mighty TNC. A number of NGOs are relatively small players who would like to 'punch above their weight' because of the urgency of the matter. ${ }^{11}$ Examples of their campaigns include valid targets such as land mines, HIV/Aids, climate

\footnotetext{
${ }^{9}$ B. Hall, 'French politics tempt IMF chief home', Financial Times, 4 February 2010.

${ }^{10}$ The International Monetary Fund has had a good crisis. Two years ago the world's main international economic institution was heading for irrelevance, its homilies ignored by rich countries, its advice despised in poorer ones and its lending unnecessary in a world flush with private capital. Today the fund is widely hailed as a flexible and innovative crisis-responder. It has committed over $\$ 160$ billion in a host of new loans and credit lines, up from barely more than $\$ 1$ billion in 2007. Its lending capacity is being trebled to $\$ 750$ billion. This warp-speed revival is the result, in part, of good luck. The sudden slump in private capital flows after the collapse of Lehman Brothers a year ago was calamitous for many emerging economies, but it was a powerful reminder of the importance of an official emergency lender' ('Back from the dead', The Economist, 17 September 2009).

${ }^{11}$ NGOs often consider that it may be better to be just about right and make a fuss now in order to put an issue on the policy agenda, than to wait for firm scientific evidence and miss the political boat to do something about the issue now.
} 
change, poverty and Third World debt. NGOs increased public awareness and pushed through agreements on the control of 'greenhouse gases' in the UN Conference on Environment and Development, the Earth Summit in Rio de Janeiro in 1992. They also helped in torpedoing the Multilateral Agreement on Investment in 1998 and created much ado in Seattle in 1999 (and many other subsequent meetings), which contributed to the failure to start a new WTO round of global trade negotiations before the meeting in Doha in 2001. No matter how justified the reasons for the campaign, these civil society protestors against global capitalism showed that the tide of globalisation could be checked and even turned back.

The anti-globalisation movement is moving beyond its radical, protest-driven, even anarchist legacy (which might have worked against it) towards a movement with a concrete agenda. Rock-throwers like the Luddites (1811-16) who destroyed factory machines, were ineffectual and irrelevant in the long term. ${ }^{12}$ The strategy of the anti-globalisation movement is to address four weaknesses of the globalisation process:

- a lack of legitimacy,

- a lack of accountability, ${ }^{13}$

- a lack of organisation and

- a lack of transparency.

The idea is not to be against globalisation across the board. Globalisation may be a favourable force that may contribute to the maximum viable economic activity that may create resources necessary to achieve other valuable social goals. The idea is to put limits on globalisation. The question is what kind of globalisation is desirable and how to achieve it?

The World Social Forum (Porto Alegre, Brazil) has made valiant attempts to put hundreds of disparate (leftist) groups under one 'organisational umbrella'. None the

\footnotetext{
${ }^{12}$ Let us not forget that a US congressman smashed a Toshiba radio cassette recorder on the steps of Capitol Hill during a protest against imports from Japan in 1987. 'US hegemony survived the exaggerated threat from Japan. But the US is now once again a fearful giant. Many Americans see trade as a peril rather than an opportunity. This turned the US from what the economist Charles Kindleberger famously called an "altruistic" hegemon into a "selfish" hegemon' (J. Bhagwati, 'The selfish hegemon must offer a New Deal on trade', Financial Times, 18 August 2008).

${ }^{13}$ The same holds for the increase in the power of special influence groups such as NGOs. Do these unelected groups of people, with sometimes questionable accountability, represent a risky shift of power towards special vested, loud and sometimes well funded private interests? Or do they represent a move towards the new 'civil society' (indeed, can anyone define this type of society)? Why does the general public sometimes believe more in these organisations, that often lack resources for rigorous analysis, than in government? Who finances them? Why?
} 
less, a unified 'global left' is far away. These groups were generally against: poverty, laissez-faire capitalism, genetically modified food, war and the US. None the less, they all use global communication networks to push for their particular social cause. They claim that the Davos Forum of the global business and financial elite has unilateral power over investment, employment and economic policies that affect hundreds of millions of people. Another claim is that the Davos Forum either ignored or made worse global social problems. The global economic and financial institutions such as the World Bank, the IMF and the WTO generally operate without democratic constraints. ${ }^{14}$ In this world, big TNCs may threaten national governments with disinvestment in order to pressure them to introduce policies that favour these firms. The Porto Alegre Forum recommends a range of activities from limiting the power of TNCs to adding new responsibilities and regulatory powers to the established international organisations such as the UN, the ILO and the World Health Organization. In this way, the anti-globalisation movement may be able to gain more leverage on the national and international scene. A popular backlash against globalisation also in rich countries may support some of these objectives.

Public opinion in developed countries is in favour of higher taxation of the rich and a general cap on exorbitant payments to corporate executives, particularly in banks that were rescued by the taxpayers' money. The public in these countries also fears that globalisation was moving too quickly. ${ }^{15}$ People in these countries worried for quite some time about delocalisation of production and job losses, and then came the global credit crunch in 2007-08. The danger is that the Western countries pass on the burden of the failure of domestic policy action and inactions from home to foreigners. Developed countries may fabricate an alibi for the domestic economic policy sins and failures (in taxation, bank supervision and

\footnotetext{
${ }^{14}$ The role and influence of international organisations may sometimes be misunderstood. 'The World Trade Organisation does not manage world trade, the World Bank is not the world's banker and the International Monetary Fund does not manage the world's money. The defining characteristic of a market economy is that no individual, or corporation, or small group, determines its directions. But since this is hard to grasp, the fallacy that decisions of big import for the world economy are being made in these conference rooms is sustained by both preening politicians inside and protesting demonstrators outside' (J. Kay, 'There is only empty talk at the world's top table', Financial Times, 14 June 2005).

${ }^{15}$ Changes that accelerated the current phase of globalisation took place throughout the 1980a. They include the opening of China, liberal changes introduced by President Ronald Reagan in the US and Prime Minister Margaret Thatcher in Britain, creation of the Single European Market, fall of the Berlin Wall, as well as the opening of India.
} 
education) and introduce protectionist measures. This is already obvious in strong 'buy domestic' campaigns which proliferated globally in 2009 in spite of loud political statements about the need to keep open markets and avoid the mistakes from 1930s which aggravated already big crises. These protectionist 'buy domestic' campaigns and multi-billion euro subsidies in Europe went so far that one of the prime achievements by the European Union (EU), its Single European Market, may be derailed. Let us recall that the objective of the Single European Market was to unleash the competitive advantages of every EU corner. To be fair to the EU countries, such domestic subsidies were also practised in other countries.

The 'buy domestic' campaigns would also violate trade obligations. ${ }^{16}$ However, if a number of countries practise the 'buy domestic' policies, they have little moral ground to accuse their partners of doing the same. They all have dirty hands. Obviously, this phase of globalisation lacks the sugar-coating of plentiful jobs (at home).

The anti-globalisation campaigners have shown that governments are not powerless. The authorities can just as easily dismantle old trade and investment barriers as they can introduce new ones. New technology, in particular the Internet, telecommunications, computing, data processing and fragmentation of the production process can offer some of the greatest economic opportunities ever for increasing living standards in all countries. Governments and the national elite in all countries (due to incompetence or indifference) have failed to explain this. However, the process needs to be coupled with balanced policies both in the rich and in the poor world. Even though global economic integration may be the best end point for the future of the world economy for the proponents of globalisation, it is more likely that other (regional) outcomes may evolve or be chosen in the future.

Globalisation may be favourable for economic efficiency including standardisation, but it can be harmful for social goals and for the widening of consumer choice. The pursuit of efficiency and more efficiency in production and conquest of markets where 'everything is permitted' has as its obvious consequence the destruction of balance in nature and the environment, as well as

\footnotetext{
${ }^{16}$ 'Based on our economic and legal analysis, the Buy American provisions would violate US trade obligations and damage the United State's reputation, with very little impact on US jobs. In a country of 140 million workers, with millions of new jobs to be created by the stimulus package, the number of employees affected by the Buy American provision is a rounding error' (Hufbauer and Schott, 2009, p. 8).
} 
urban sprawl. Deprived of access to natural livelihoods, these developments may in extreme cases even contribute to human trafficking and trade in organs.

\section{Definition}

The vogue term 'globalisation' has not yet been well or clearly defined. Many people have an opinion about globalisation, they argue about it, but without a clear idea and definition of what it actually means. The Economist refers to a report that found over 5,000 competing definitions of globalisation. ${ }^{17}$ Not everything is in a definition, however, most things or notions necessitate a definition for a reasonable discussion and analysis.

Some commentators assume that globalisation means international, worldwide and/or everywhere. Others use globalisation to describe almost all aspects of the present capitalist era of world economy. As such, it may mean different things to different people. Hence, this fuzzy, contested and controversial, but powerful metaphor is overused, misinterpreted, often abused and very often misleading.

Let us start with the definition of globalisation found in the Oxford English Dictionary. This dictionary defines globalisation as

The action, process, or fact of making global; esp. (in later use) the process by which businesses or other organizations develop international influence or start operating on an international scale, widely considered to be at the expense of national identity. ${ }^{18}$

The emphasis in this definition of globalisation is on the standardisation influence that firms have on those that they deal with internationally.

A noted 'early' definition of globalisation stated:

Globalisation refers to the multiplicity of linkages and interconnections between the states and societies, which make up the modern world system. It describes the process by which events, decisions, and activities in one part of the world can come to have significant consequences for individuals and communities in quite distant parts of the globe. Globalisation has two distinct dimensions: scope (or stretching) and intensity (or deepening). On the one hand it defines a set of processes which embrace most of the globe or which operate world-wide; the concept therefore has a spatial connotation. Politics

\footnotetext{
${ }^{17}$ The Economist, 'Globalisation', 20 July 2009.

${ }^{18} \mathrm{http}: / /$ dictionary.oed.com/ (accessed on 12 July 2010).
} 
and other social activities are becoming stretched across the globe. On the other hand it also implies an intensification in the levels of interaction, interconnectedness or interdependence between the states and societies which constitute the world community. Accordingly, alongside the stretching goes a deepening of global processes (McGrew, 1992, p. 23).

The problem with this vision is that it does not mention TNCs, as if the business community is outside this process. Globalisation is about changing forms of human and business relations. It shortens time and 'reduces' space for such contacts which become more intense and broader. Events in one part of the world instantaneously influence events elsewhere and vice versa. ${ }^{19}$

Ietto-Gillies (2003, pp. 139-140) argued that most definitions of a complex phenomenon of globalisation 'boil down to the fact that globalisation is both a process of geographical/spatial outreach and of an increased degree of interconnectedness and interdependence between people, groups, and institutions based in different countries of the world'. As a spatial outreach process, globalisation is not new. However, what is different this time from many earlier 'outreaches' is the central role played by the TNCs (corporate globalisation).

Globalisation meant that business spread from the developed countries to the developing ones. At present, it expands both ways, as well as among the developing world where the number of the global middle-class and rich consumers is on the rise. Resource-lacking China relentlessly expands its business and investment relations with Australia, Latin America and Africa. Global competition (for those that take it that this means globalisation) entered each other's backyard. So, the more the business horizons widen, the more freedom for action, paradoxically, narrows. Therefore, globalisation may not be fully equated with 'Americanisation'. A Chinese computer maker Lenovo, for instance, bought the personal computer business from one of the best-known American companies IBM in 2005. Lenovo had the right to use IBM's logo on its products for five years. None the less, Lenovo was so confident in the quality and image of its own products that it used IBM's logo only for a period of three years. This is just a small example which may partly show how the global predominance of the developed Western world is seriously challenged from other regions for the first

\footnotetext{
${ }^{19}$ 'The financial products group at AIG brought down America's leading insurer, and 120,000 people with it. It was based in London and employed barely 100 of these people' (J. Kay, 'Too big to fail?', Financial Times, 22 July 2009).
} 
time since the $17^{\text {th }}$ century.

Fratianni and Marchionne (2011) argue:

In a loose sense, globalisation means that international trade is not choked by man-made restrictions and that most countries exploit and gain from cross-border transactions. In a strict sense, globalisation implies that transactions among residents of distant countries are just as likely and intense as transactions among residents of neighbouring countries or among residents of communities located inside a country. The facts are clearly more consistent with the loose concept of globalisation than with the strict one. International trade is far from being perfectly globalised.

This definition notes the necessary freedom for international business transactions, but is aware of the fact that there are many obstacles to such freedom. Combes et al. (2008, p. xviii) look at globalisation as 'the gradual integration of national and regional economies, as well as the reallocation of activities that this integration might induce'. That is the way how globalisation may operate, however, what about its effects?

The World Bank (2009, p. 170) takes globalisation to be 'a euphemism for falling transport and trade costs'. This is quite a narrowed-down one-dimensional observation and definition. The $\operatorname{OECD}(2010$, p. 20) defined globalisation in a wider way as 'a process by which the people of the world are unified into a single society and function together'. Economists refer to globalisation usually in the narrower sense. It involves 'integration of national economies into the international economy through trade, foreign direct investment, capital flows, migration and the spread of technology' (p. 20). The forces that have contributed crucially to this process according to the OECD include: the liberalisation of capital movements; deregulation financial services; the further opening of markets to trade and investment which gave an impetus to the deepening of international competition; and the central role played by information and communication technologies in the economy. While this definition highlights the positive side of globalisation, its effects on the distribution of income are put aside. The migration of jobs from the West to the East produced a backlash in the Western world and a wave of 'buy domestic' protectionist policies.

Strobe Talbot, the US Deputy Secretary of State (1994-2001) during the Clinton administration discussed the issue of globalisation in the following way:

Here is one optimist's reason for believing unity will prevail over disunity, integration over disintegration. In fact, I'll bet that within the next 
hundred years (I'm giving the world time for setbacks and myself time to be out of the betting game, just in case I lose this one), nationhood as we know it will be obsolete; all states will recognize a single, global authority. A phrase briefly fashionable in the mid- $20^{\text {th }}$ century - 'citizen of the world' - will have assumed real meaning by the end of the $21^{\text {st }}$ century.

All countries are basically social arrangements, accommodations to changing circumstances. No matter how permanent and even sacred they may seem at any one time, in fact they are all artificial and temporary. Through the ages, there has been an overall trend toward larger units claiming sovereignty and paradoxically, a gradual diminution of how much true sovereignty any one country actually has...

Globalization has also contributed to the spread of terrorism, drug trafficking, AIDS and environmental degradation. But because those threats are more than any one nation can cope with on its own, they constitute an incentive for international cooperation. ${ }^{20}$

This is a long-term vision of the global American-style melting pot. At the end of the day, a single global and unified 'grey' standard for the masses would prevail throughout the world, while the exclusive and colourful top cluster of those that hold economic and political power would be able to handle with ease such a homogeneous 'grey' world. One wonders if there will be any room for at least some differences.

Globalisation brings certain ideological standards in the form of modern pseudointernational (global) values. Communists had the same plan and policy design. ${ }^{21}$ In this respect the across-the-board 'forced' standardisation of everything including ideas, does not differentiate globalisation from neo-communism. Both have the same final policy goal: one global standard for all and everywhere including a grey consumer monoculture mass. ${ }^{22}$ Whether Talbot's prediction will be realised at the end of the $21^{\text {st }}$ century nobody knows. However, there is now a strong resistance to such an outcome, at least in the Middle East. Certain Muslims, in addition, have

\footnotetext{
${ }^{20} \mathrm{~S}$. Talbot, 'The birth of the global nation', Time Magazine, 20 July 1992, p. 70.

${ }^{21}$ Evolutionary and spontaneous outcomes such as convenience in practice and experience, as well as 'network externalities' without government intervention (such as evolution of languages, customs, gold standard, markets) are put aside.

${ }^{22}$ Evola (1934, pp. 461-462) argued that the Soviet Bolsheviks and those that want to Americanise the world have the same objective and that both of them represent two sides of the same coin ('due faccie di una stessa cosa').
} 
their own and virile expansionist agenda through migrations, demography, unwillingness to integrate in the host country and, some would even argue, ${ }^{23}$ through terrorism. Some also claim that Islam is 'a political movement masquerading as a religion'. ${ }^{24}$

For some economists globalisation refers to the choices and strategies, as well as the shape, direction and significance of activities of TNCs. 'Globalisation has been defined in business schools as the production and distribution of products and services of a homogeneous type and quality on a worldwide basis. Simply put providing the same output to countries everywhere' (Rugman and Hodgetts, 2001, p. 333). This falls under Friedman's (2006) understanding of a flat world. For decades, the IMF has been the main tool for such a 'linear' approach in which it offered its one-size-fits-all economic remedies.

Ethier defines globalisation as 'the vertical fragmentation of production across countries' (2011). The fragmented production process makes it possible for firms to operate at various and dispersed international locations. At the same time, there is an increased interdependency among various parts of the firm, as well as among various geographical locations. The Economist defines globalisation as 'the more or less simultaneous marketing and sale of identical goods and services around the world'. ${ }^{25}$ This definition does not refer to the production side of the globalisation equation and neglects the horizontal and vertical linkages necessary in the fragmented production chain. None the less, it also notes that firms approach globalisation in two different ways. One is to offer few concessions to the local market and tastes. Bic, Heineken or Gillette offer the same product everywhere. Production of their output is standardised, homogenised and located in a few production sites. Another approach is to tailor output to accommodate at least a part of local preferences. Pepsi, Schweppes or Coca-Cola do not taste the same when compared from one country to another.

In their Arsenale, the industrious Venetian shipbuilders conceived the production

\footnotetext{
${ }^{23}$ Recep Tayyip Erdogan is the leader of the Justice and Development Party (Adalet ve Kalkinma Partisi, or AK) in Turkey. 'His pro-Islamist sympathies earned him a conviction in 1998 for inciting religious hatred. He had publicly read an Islamic poem including the lines: 'The mosques are our barracks, the domes our helmets, the minarets our bayonets and the faithful our soldiers'... 'He was sentenced to 10 months in jail, but was freed after four. However, because of his criminal record, he was barred from standing in elections or holding political office' ('Turkey's charismatic pro-Islamic leader,' $B B C, 4$ November 2002, http://news.bbc.co.uk/2/hi/europe/2270642.stm, accessed on 11 July 2010.) None the less, he won two consecutive elections and became the Turkish Prime Minister in 2003 and 2007.

${ }^{24}$ Leading article: 'An end to tolerance', The Sunday Times, 12 February 2006.

${ }^{25}$ The Economist, 'Globalisation', 20 July 2009.
} 
assembly line in one place in about 1450 . They produced (assembled) roughly 200 seagoing ships a month ( 50 a week or seven a day). That was at the time when it took English carpenters months to put together just one seagoing ship. Ely Whitney further developed the assembly line for rifles (1801). Later, between 1908 and 1915, Henry Ford developed the assembly line for cars. Those days of complete production in one place are gone, but can they return?

Krueger defined globalisation as 'the increasingly rapid exchange of ideas, people, and goods made possible by falling transport costs and technological advances, all leading to the closer integration of the world including - but not limited to - the economy. ${ }^{26} \mathrm{~A}$ fall in shipping costs made globalisation possible in part. Those costs fell so much that 'it often now costs more to ship a container by road 100 miles from a port to its final destination than it does to move the container by sea from China to Europe'. ${ }^{27}$ However, when oil prices were $\$ 20$ per barrel in 2000, it cost only $\$ 3,000$ to ship a container from China to North America. At prices of $\$ 200$ per barrel, it will cost $\$ 15,000$ in transport costs to ship a container from China to the east coast of the US. ${ }^{28}$ If demand for liquid fuels continues to grow without increased efficiency in fuel consumption, without new technologies, without new oil deposits, trade costs would increase. Market liberalisation and new technologies contributed to globalisation and the 'flattening' of the world, but increasing costs of energy and transport would partly reverse the flattening process and 'crumple its surface'. Lipsey (2011) noted that this might bring 'a resurgence of many forms of local production'. This is to say that certain aspects of the current phase of globalisation can be undone; just as was the case with previous globalisation phases.

The globalisation pendulum swings back and forth in business. Outsourcing has been widespread since the early 1990. It was based on the spatial fragmentation of production based on the disaggregation of supply and value chains. However, recession may prompt a re-evaluation of benefits of splitting of production and supply chains, and costs of vertical integration. Boeing, for instance, runs a complex and disparate supply chain. In order to mend this chain Boeing had to buy one of the component suppliers for almost $\$ 600$ million. ${ }^{29}$ Many businesses from

\footnotetext{
${ }^{26}$ A. Krueger, 'Educating globalisation's Luddites', Financial Times, 16 April 2004.

${ }^{27}$ R. Wright, 'Engines of globalisation: the story of Maersk', Financial Times, 2 October 2006.

${ }^{28} \mathrm{~J}$. Rubin and B. Tal, 'Will soaring transport costs reverse globalization?', StrategEcon, 27 May 2008, p. 4, available at http://research.cibcwm.com/economic_public/download/smay08.pdf (accessed on 11 July 2010).

${ }^{29}$ 'Reaggregating the supply chain’, Financial Times [Lex], 15 July 2009.
} 
the West moved quickly and aggressively expanded into Central and Eastern Europe from the end of 1990s. When the economic downturn came from 2008, these TNCs were very exposed. Many had to scale down and close their operations. ${ }^{30}$ There are also swings in ideology. In 2008, the global idea was that China's economic fortunes could not be decoupled from the strong US economy. In 2009, China had a strong economic growth, while the US economy floundered. China's success was globally taken to be self-evident. In addition, China had had a relentless and unmatched growth in scientific research since the early 1980s.

Others think of globalisation as a liberal system for trade, investment and integration of the world economy (a move away from segmented national markets). For certain political scientists, globalisation means a challenge to national authority and its hand-over to supranational authorities. For sociologists, globalisation may mean a creation of global social interaction that provokes adjustments that challenge local social structures. This may marginalise certain social groups that could violently resist such a change.

'Thanks' to al-Qaeda many realised that globalisation goes well beyond links that bind TNCs, producers, traders and bankers. For these, globalisation is linked with and invigorated by new technologies in communications and information processing. It is a sum of techniques that are at the disposal of private players and states. Yet for others, globalisation is an incentive to the reform process in economic strategy in many countries as outward-looking economic models replace inward-looking and TNC-hostile economic policies (although the global credit crunch of 2007-08 and 'buy domestic' campaigns have shaken the national economic openness). So globalisation may be openness to trade and investment with foreign and more and more geographically distant countries. Others look at globalisation as a process that alters interactions among agents across space; still others equate globalisation with economic integration. ${ }^{31}$

Brakman et al. (2009, p. 56) define globalisation as 'the growing interdependence between countries through trade and/or increased factor mobility'. This explains the operation of globalisation, but not its full effect which may ultimately be global

\footnotetext{
${ }^{30} \mathrm{~J}$. Cienski, 'East Europe groups have to reshape ambitions', Financial Times, 15 July 2009.

${ }^{31}$ 'Globalisation is no more than an (admittedly ugly) name for the process of integration across frontiers of liberalising market economies at a time of rapidly falling costs of transport and communications' (M. Wolf, 'How trade can help the world', Financial Times, 3 October 2001, p. 15).
} 
standardisation of goods, services and even thoughts. Apart from a partial integration of international production, globalisation brings risks and disruptions. Volatile capital flows, speculative attacks on currencies, financial crises and unpredictable reallocation of jobs are obvious examples of the increased economic and social vulnerability of many countries, in particular in the developing world. To finalise the issue, Henry Kissinger called globalisation 'another name for the dominant role of the United States. ${ }^{32}$ Martin Wolf confirmed such a view: 'Globalization is not inevitable. It depends on politics. In today's world, it depends above all on US politics' (Wolf, 2005, p. 8).

Strange (2003, p. 137) takes a political economy look at globalisation and defines it as 'the coincidental effects of three major changes: the accelerated internationalization of production; the sharply increased mobility of capital; and the greater mobility of knowledge or information, from communication of messages to the transfer of technology'. This definition attempts to describe the stretching of the globalisation process. What are the spatial effects of these 'three major changes' on local development, income distribution and culture?

Uniformity and homogeneity in the modern world may be a heavy price to pay for the new or 'better' standardised products that we consume. This introduces an ever-present potential for the neo-communist risk that everyone eats and drinks the same, is dressed the same, shops in the same way, uses homogeneous (perfectly substitutable) goods and services, and finally may even, or is forced to, perhaps, think 'the same'.

It colonises by annexing not territory but the thinking and behaviour of a multiplicity of policymakers at a variety of scales. So there are no formal imperial institutions, merely a shifting constellation of corporations, bordercrossing networks, and territorially-defined political units representing, or at least ruling over, distinct communities' (Lovering, 2006, p. 222).

If someone is not 'in step' with these global developments (regardless of their pseudo-democratic or legal appearances and sugar-coating), well, then ... he or she or they may court trouble from the central globalisation 'politburo'. Hence this may bring us back to the beginning of this section and to the definition suggested by the Oxford English Dictionary.

\footnotetext{
${ }^{32} \mathrm{H}$. Kissinger, 'Globalisation: America's role for the millennium', The Irish Independent, 13 October 1999.
} 


\section{For and Against Globalisation}

Proponents point, on the one hand, at benign effects of globalisation: increased economic opportunities and growth, and decrease in inequality and poverty among the countries around the world (but not necessarily within countries). They argue that globalisation as a new phenomenon, cannot be compared with previous phases of capitalist development as this one has nothing to do with the past. Certain income disparities may be acceptable if they are merited and if they support a general economic progress. Labour has to pass through continuous adjustments, as it is, according to this school, better to have a mobile than an equal society. This group announces the 'death of distance' and 'weightless economy' (as spatial distance is no longer one of the main characteristics of the world economy), the 'death of national economic policy' (particularly trade, industrial and monetary) and the 'collapse of the nation-state'. This group emphasises the central role of TNCs in the globalisation process as they shape the international geography of production with their decisions to invest in certain locations or to leave them. They produce global, that is, standardised (identical), goods and services for consumers all around the world. Production becomes detached from consumption in national economies as they are both homogenised and integrated in the global system.

Sceptics, on the other hand, refer to the socioeconomic costs of globalisation: increasing income gaps and inequality around the world, uneven and unfair geographical and social distribution of gains (more than a billion people live on less than a dollar a day, many of them have never made a phone call), uprooting of local brands, social tensions, environmental degradation and growing intolerance towards political diversity (many want to defend their right to be wrong). They argue that potential gains of the current phase of globalisation are largely overblown. Is globalisation 'truly global'? Local forces are still strong and play a significant, useful and meaningful role. ${ }^{33}$

The task and influence of the state is not diminishing: it is evolving alongside globalisation and it is changing its role and authority. It is true that the behaviour and actions of TNCs shape globalisation to a large extent, but investments and sales of TNCs are mainly concentrated in specific geographical areas (principally the developed world). To operate successfully, TNCs need certain preconditions

\footnotetext{
${ }^{33}$ Even though most TNCs are loyal to their own spirit (not to their nation of origin), there are certain TNCs that may not easily give up their national roots, for example, the Bank of China or the Deutsche Bank.
} 
including appropriate infrastructure and educated labour. They also need the security of property and person that is normally provided by the state authorities. Large-scale production, efficiency and homogenisation of tastes and consumption patterns are exaggerated by the promoters of globalisation. Local and individual tastes and preferences, particularly if compounded with an increase in income, become reinforced. Consumers search for differentiated, often custom-made, goods and services, and many are able, ready and willing to pay for them.

Despite grand talk about globalisation, even the biggest TNCs generally sell most of their output in the domestic market of the country where they produce. While, there was a huge increase in absolute volume of FDI in the world, as well as liberalisation of capital markets, one important global thing did not happen. Contrary to the situation around the start of the $20^{\text {th }}$ century, the new wave of globalisation had not achieved freedom of labour movement at the turn of the $21^{\text {st }} .34$

Critics of globalisation recall The Communist Manifesto (1848) and Marxian prophecies: unchecked global capital movements and corporations all around the world; wild capitalism and globalisation that destroy the social and economic structure of society. ${ }^{35}$ These critics say that global TNCs put profits before people. When these TNCs start talking about how they will no longer put profits first, people (correctly) think that they are lying. ${ }^{36}$

\footnotetext{
${ }^{34}$ [There are] '...five parallels between the United States today and the United Kingdom a century ago: overstretched, physically and financially; great power rivalry, with China now in Germany's role; an unstable alliance system, with disintegration of the transatlantic relationship; rogue regimes (then Serbia, now Iran and North Korea); and revolutionary organizations (then Bolsheviks, now al-Qaeda)' (Wolf, 2005, p. 7).

${ }^{35}$ 'The bourgeoisie has through its exploitation of the world market given a cosmopolitan character to production and consumption in every country. To the great chagrin of Reactionists, it has drawn from under the feet of industry the national ground on which it stood. All old-established national industries have been destroyed or are daily being destroyed. They are dislodged by new industries, whose introduction becomes a life and death question for all civilised nations, by industries that no longer work up indigenous raw material, but raw material drawn from the remotest zones; industries whose products are consumed, not only at home, but in every quarter of the globe. In place of the old wants, satisfied by the production of the country, we find new wants, requiring for their satisfaction the products of distant lands and climes. In place of the old local and national seclusion and selfsufficiency, we have intercourse in every direction, universal inter-dependence of nations. And as in material, so also in intellectual production. The intellectual creations of individual nations become common property. National one-sidedness and narrow-mindedness become more and more impossible, and from the numerous national and local literatures, there arises a world literature'. (K. Marx and F. Engels [1888 ? English translation] Manifesto of the Communist party, p. 6; available at http:// www.marxists.org/archive/marx/works/1848/communist-manifesto/ (accessed on 11 July 2010)

${ }^{36}$ The Economist, 'A survey of globalisation', 29 September 2001, p. 4.
} 
The critics of globalisation have certain valid points. They point to the sweet and attractive Potemkin village-type outcomes that were fake and neglected by the globalisation proponents. Paul Krugman, for instance, wrote:

The promise of export-led growth has failed in too many places. In particular, Latin America has signally failed to replicate Asia's success:

Latin nations have liberalized, privatized and deregulated, with results ranging from disappointing (Mexico) to catastrophic (Argentina) ${ }^{37}$

However, John Kay argued: 'The essence of economic globalisation is specialisation by function and skill on an unprecedented scale. I cannot tell you how to get rich but I can tell you how to stay poor. Do not become involved in the global marketplace' ${ }^{38}$ In any case, a large part of modern trade is intra-industry. This is the outcome of the fragmentation of the production process and specialisation for the global market.

The expectation and promise that financial globalisation would allocate capital in a superior way compared to controlled markets remained largely unfulfilled. Many countries, especially in South-East Asia piled up huge foreign currency reserves after their credit crunch in 1997, which is some way represents a waste of resources. Economic nationalism (buy domestic campaigns) skews demand towards home goods, while ageing population tilts demand towards many services that could be provided only locally (cleaning, cooking, rehabilitation, medical and social care). Ageing population and the linked change in the structure of demand would notably contribute to a change in global connections.

Another cost of globalisation can be found in the examples of countries such as Mexico, Thailand, Indonesia, South Korea and Russia, which suffered financial crises in the second half of the 1990s. Without the exposure to global capital markets, the crises would not have developed as they did. There are no safe havens from economic storms in a globalised world. Critics of this view argue that these countries would not have experienced such rapid development prior to the crises without such global exposure. In any case, one ought to be fair and observe that certain global tendencies were already present, well before the current wave of globalisation. For example, there was (for whatever reason and by whatever means) a spread of certain European languages outside Europe; a spread of Islam in Africa, Asia and Europe; and a spread of Christianity in Latin America. This

${ }^{37}$ P. Krugman, 'The Good News', The New York Times, 28 November 2003.

${ }^{38}$ J. Kay, 'Global business deserves a peaceful May Day', Financial Times, 28 April 2004. 
was often linked with a profound subordination of the conquered population and annihilation of the local culture.

There is still an unresolved and disputed political problem: under the current wave of globalisation, is the protection and spread of human rights (pretext) sometimes more important than state sovereignty? In the earlier eras of globalisation, the pretext was the Christianisation of the barbarians or Islamisation of the infidels.

Globalisation has never been either uniform or fully universal. It is also reversible. Just recall relatively recent disintegration phases in the world economy during 1930s, the closing of the Soviet Union and China when they turned communist or the wide pursuit of import substitution policies during 1960s and 1970s in many developing countries. Following the global credit crunch of 200708 , faith in pure neoliberalism and self-regulating market fundamentalism evapourated on many fronts.

Child labour, begging, theft and prostitution in poor countries would certainly decline if globalisation opened advanced countries' markets to the products made by the children's parents. Even though globalisation spreads symbols of highly dubious value such as Coca-Cola, ${ }^{39}$ McDonald's, MTV, Halloween, chewing gum, ${ }^{40}$ or reality shows, it also spreads basic values such as the rights of women and children. However, it is unfortunate that the latter takes place at a much slower pace. Globalisation also provides an opportunity as it pulled out of deep poverty (but not more than that) hundreds of millions of people in the developing world.

Globalisation spreads useful ideas. Following a period of rapid expansion during 1990s, air travel in China became one of the most dangerous in the world. After a big crash in the region in 1994, Boeing offered free training workshops to traffic controllers and the staff of air transport companies. A new rulebook followed with the support of both Boeing and Airbus. The 2008 Olympics in Beijing gave another impetus to China to improve safety in air transport. The outcome is that the

\footnotetext{
${ }^{39}$ In India, a next to total monopoly of the domestic market for fizzy drinks was in the hands of two companies: Coca-Cola and Pepsi. Following a successful campaign by the local NGOs and populist politicians, in 2006 a quarter of India's 28 states banned the sale of Coca-Cola and Pepsi on the grounds of concern for the health of consumers (Editorial, 'Coke and Pepsi canned', Financial Times, 11 August 2006). Similarly, Venezuela banned the sale of one of the most powerful symbols of global capitalism, Coke Zero, on unspecified health grounds (B. Mander, "Venezuela bans Coke Zero, citing "harmful" ingredients', Financial Times, 11 June 2009).

${ }^{40}$ One thinks of the particular consequences of chewing gum, which pollutes lifts, pavements, and the underside of desks and chairs.
} 
accident rate in China is now among the lowest in the world (Romer, 2010, p. 11).

The debate about globalisation is often about jobs (social dimension). Supporters argue that it is beneficial and that it creates jobs, while critics argue the opposite and say that jobs migrate to trading partners and competitors, as well as that globalisation destroys the natural balance in the environment. Certain segments of labour in all countries are suspicious of globalisation, as they no longer perceive the national government as a guaranteed protector of their concerns against external threats. The protectionist 'buy domestic' campaigns of 2009 reversed these fears by certain national (car making) industries. To counter fears that come from globalisation, the best long-term policy response may be to advance the possibilities for education and training, as technical progress and globalisation have a strong bias against unskilled workers. Lifelong education is necessary, as many of the most demanded qualifications now did not exist a decade ago. Such a trend may continue in the future.

As far as firms are concerned, efficiency-seeking enterprises, particularly some TNCs, search for seamless and wide international markets regarding trade and investment. They basically seek to break constraints on their business. On the one hand, the globalisation of economic activity is making national frontiers less divisive than ever before. ${ }^{41}$ Such worldwide economic integration and integrated international production of goods and services whereby competitors are in one another's backyard are made possible by the expansion of information and telecommunication technologies. ${ }^{42}$ This process is sometimes inverted, on the other hand, by the wide spread of bilateralism and regionalism sometimes pushed by relatively inefficient firms and governments that are driven by short-term election interests, even though the conditions for a relatively successful regional integration process, such as that in Western Europe, may be largely absent.

Liberal trade and foreign investments (globalisation) regimes may be partners, not adversaries, of social agendas, but they ought to be coupled with effective

\footnotetext{
${ }^{41}$ Increased international mobility of factors, increased international intra-firm transactions, expanding international cooperative arrangements between firms, the increasing importance of knowledge, as well as a reduction in transport and communication costs, support the process of globalisation and are constituent parts of it. In these circumstances, individual actions of national governments may not increase global welfare (pollution is an example) and certain supranational rules may be necessary in order to deliver more beneficial general outcomes.

${ }^{42}$ Trade is relatively more concentrated within regions than FDI. This suggests that trade plays a more prominent role in intra-regional integration arrangements, while FDI has a greater influence on global integration (UNCTAD, 1993, p. 7).
} 
national and international institutions that ease and regulate adjustment problems (such as the 'polluter-pays' principle). Globalisation may bring adjustment costs in the affected industries and labour markets, but this may be only transitory. The gradual opening up of markets in Japan during the 1970s, and later in South-East Asia during the 1980s, Eastern Europe from the early 1990s and in China from the second half of the 1990s, demonstrates that as a country grows wealthier it ceases to be competitive in the production of labour-intensive goods. Such a country becomes at a later stage an importer of some of these goods and concentrates its production on higher value-added activities.

Regional integration (a second-best solution) may be a promising form of supranational governance in areas where there is a strong case for coordination and harmonisation of national policies. Integration may resolve conflicts through positive cooperation within a cosy group but, if pushed to the limit, it may undermine multilateral (first-best) trade and investment systems and fragment the world economy into conflicting regional blocs. Regionalism and multilateralism (globalisation) need not necessarily conflict. If the regional blocs cooperate and if they adopt liberal external trade and investment policies, the outcome may be an overall welfare improvement. The pace of international trade liberalisation from the 1960s until the end of the 1990s, as well as the extension of the General Agreement on Tariffs and Trade (GATT) into new areas such as services and agriculture might have been much slower in the absence of challenges posed by the great progress in European integration. Perhaps the debate should not be between regionalism and multilateralism, but rather between liberalism and controlled interventionism.

\section{Global Standards}

The imposition of global standards (regulation that imposes uniformity) may have its justification for relatively new and standardised goods and services. These include copiers, fax machines, computers, TV sets, better medicines or mobile phones together with the derived gadgets, otherwise communication and exchange of information might be difficult and costly. But it may stop there. The imposition of global standards for traditional goods (food, for example) with the exception of health and the environment may not easily be justified. If needs, choices and tastes for certain types of food are strongly locally specific (even the thickness of pizzas throughout Italy differs), why should one favour or impose global Pizza Hut type 
standards? For many services, regionalisation is more important than globalisation. 'Managers need to change their thinking as the end of globalization is here. Managers must "think regional and act local" (Rugman, 2002, p. 15). In the situation with global economic crises and falling exports in multilateral terms, regional economic deals do not seem to be such a bad idea (trade is good, even if it is within a limited group of countries). Hence, the regional preferential and free trade deals proliferate.

How globalised are the largest 100 companies in Europe and the US? OECD (2007, p. 32) found that they were largely similar. These TNCs generate two-thirds of their revenue in their home area and one third abroad. Rugman and Oh (2011) report similar findings. Hence, data demonstrated evidence that globalisation as popularly understood, does not exist (Rugman and Oh, 2008, p. 13). Certain economic data (trade, sales) regarding globalisation may be exaggerated and misinterpreted, while others such as growing restrictions on global labour migration may be ignored and overlooked.

Gray of the London School of Economics claimed that people are losing faith in globalisation, and:

[L]ed by the United States, the world's richest states have acted on the assumption that people everywhere want to live as they do. As a result, they failed to recognise the deadly mixture of emotions - cultural resentment, the sense of injustice and a genuine rejection of western modernity - that lies behind the attacks on New York and Washington ... The ideal of a universal civilisation is a recipe for unending conflict, and it is time it was given up. ${ }^{43}$

It is not that the people who live outside the Western world cannot adopt a liberal attitude, rather that there are social, cultural and institutional barriers that prevent a fast transfer of western standards, values, culture and institutions elsewhere. One must also consider the choices of the 'recipients'. Do they really want and need what is exported or 'imposed' on them? Lipsey argued that:

... it is policy imperialism to argue that the poor must accept the standards of environment and labour protection that the rich ones can now afford (but could not when they were poor) (Lipsey, 2004, p. 12).

Wal-Mart, the world's most powerful American retailer with 'prices that nobody could beat', failed in and withdrew from Germany in 2006 and earlier from South

\footnotetext{
${ }^{43}$ The Economist, 'Is globalisation doomed?', 29 September 2001, p. 14. The reference here is to the attacks of 11 September 2001 in New York.
} 
Korea. German consumers already profited from local competition between Lidl and Aldi, and they did not want to spend time driving long kilometres to Wal-Mart stores and changing their embedded shopping habits, while the hypermarketshopping model was not in line with local tastes in South Korea. Local conditions may not support the one-size-fits-all approach.

There are deeply embedded national/regional differences and preferences that cannot be uprooted or globally standardised. For instance, many people in Europe and in the Anglophone world use the Internet as a huge and handy library, mostly, but not exclusively, for work. Most Chinese use it differently: for many of them the Internet is a huge playground used for entertainment. They navigate almost entirely by using the mouse. Typing thousands of different Mandarin characters or drawing them with a mouse before conversion in to a computer readable sign is quite irritating. Therefore, the Chinese websites have hundreds of multi-coloured links that make life, navigation and search easy for the Chinese. Such a glut of sites that compete for attention may look tiresome and unfriendly in the eyes of Europeans and in the Anglophone world. In India, for example, the consumption habits are linked to the Hindu religious calendar and marriages. The calendar sets the time when it is fortunate and good to buy gold or other items such as a vehicle. The Diwali festival is the pivotal point for this. There are some 1.2 billion consumers in India. Most of them do not fancy pre-packed goods. Would it be a smart, fast and cheap global marketing strategy to try to convince them to change their deeply rooted preferences and habits? Similar 'problems' with global standardisation may be found in China, where the calendar also dictates the time to have a haircut or to buy shoes. However, these problems may be even bigger than in India, as China has a bigger population that needs to rewire its deeply rooted practices.

Globalisation may be less rewarding to all firms than was ambitiously predicted and expected. Consumers often demand and pay for many niche goods and services that single them out from the crowd. This is why globally oriented Starbucks, the American coffee shop chain, decided to close 61 out of 84 shops in Australia in $2008 .{ }^{44}$ Many Australians grew up on a quality diet, including superb coffee, introduced by the Italian immigrants. The global and standardised Starbucks-tasting coffee and muffins was not well received in Australia after the locals had first tasted the Italian version.

There was a faulty premise and a vision that all people are culturally

${ }^{44}$ P. Smith, 'Starbucks tastes defeat in Australia', Financial Times, 29 July 2008. 
homogeneous in that they think, act and most of all, shop alike or as Americans ${ }^{45}$ do (consumer monoculture); that there exist institutional bases for political democracy; and that citizens are aware of their duties to one another and to the state. Checks and balances are mixed; there is mistrust vis à vis the government and state administration especially if it is deeply rooted in dictatorship, authoritarian and bureaucratic conduct, as well as in corruption. With no long-term reform, education and trust building, any attempt to transfer 'global' (social) standards quickly would fail, and fail miserably, in many parts of the world. It should not be forgotten that 'it took 400 years for England to develop from that stage to its present one. To do the same elsewhere in half the time of 200 years would be a tremendous achievement; to aspire to do it in 25 or 50 years may be to court disaster' (Lipsey, 1992, p. 755). ${ }^{46}$

Local differences tend to be stubborn. Until the world becomes homogeneous, adaptation towards local preferences, conditions and capabilities will be necessary. Globalisation problems, which appeared in the form of concerns over the lack of progress in the WTO or in the Multilateral Agreement on Investment illustrate signals of regional or even local power (triad: US, EU and Japan, as well as the developing world).

The greatest and matchless advantage of free markets and globalisation is that they give free choice to consumers. Economic interactions are voluntary, so consumers are free to choose, for example, between local and global goods and services. But, this is only on the surface. If global products are advertised aggressively by large $\mathrm{TNCs},{ }^{47}$ including campaigns that are often beyond the financial capacity of local competitors, then the 'free choice' of consumers may be

\footnotetext{
45، Americans tend to believe that we do everything better than anyone else. That belief makes it hard for us to learn from others' (P. Krugman, 'French family values', The New York Times, 29 July 2005).

${ }^{46}$ Institutional elements such as clear property rights are very important for foreign investors. However, the mere transfer of these solutions from the developed countries elsewhere is not a sufficient condition for successful economic performance. For example, while Russia has introduced a system of private property rights, China has retained the general socialist legal system. None the less, domestic and foreign investors regarded China as a promising location for investment and this country became one of the prime locations for FDI. There was a strong credibility that investments would be protected. In contrast, this credibility was lower in Russia in spite of the property rights system, which is one reason why Russia continued to score much lower than China as a location for manufacturing FDI. None the less, Russia's enormous natural resources, certain manufacturing potential and growing market are and will be strong attracting points for FDI.

${ }^{47}$ Apart from Russians, Poles and Finns, few people cared much about vodka prior to the early 1980s. Then a Swedish firm, Absolut Vodka, launched one of the most successful advertising campaigns in the US. Following that, vodka became one of the most popular spirits in the world.
} 
restricted and the local producers (and certain dimensions of the local culture and health) may be damaged. 'Soft drink manufacturers around the world have been overwhelmed by the entrance of Coca-Cola and Pepsi into their home markets. Local ice cream manufacturers find they are unable to compete with Unilever's ice cream products' (Stiglitz, 2002, p. 68).

The 'hunting ground' for advertisers and sellers of goods, services and ideas, no bigger than a human skull (Kalajić, 1979, p. 6), was well understood by Jesuits, centuries before the modern advertising campaigns of Coca-Cola and McDonald's. Jesuits recognised that if you can shape someone's mind when that person is young, you may have it for life. In January 2006, for example, in order to avoid official warnings about new heavy-handed EU legislation against obesity, the Union of European Soft Drinks Association (UNESDA) (including Coca-Cola and Pepsi) introduced self-regulation measures and voluntary restrictions about marketing soft drinks to youngsters. ${ }^{48}$

\section{Rebottled Old Stuff or Something New?}

The essential spirit of the most recent wave of globalisation does not bring much that is new. "Critics of "globaloney" are right to assail the historical illiteracy that marks most claims of novelty associated with these conceptions of globalisation' (Scholte, 2008, p. 1477). The general quest is for international openness: more freedom for trade in goods and services, and for capital mobility (FDI). The economic role of national frontiers declines as national economies merge (integrate) in a single interdependent 'global' unit. In a nutshell, the idea is to return to the essentials of the system that was prevailing during the first big wave of globalisation (1850-1914). An important fact and a measure of economic globalisation is often overlooked: measured by the export/GDP ratio, international trade was more important for the economies of industrialised countries in 1913 than was the case in 1950 (which was well after the Second World War) (O'Rurke and Williamson, 2000, p. 30). 'Re-globalisation' may be a more appropriate term for the second big wave of globalisation that started and continued from about 1980s.

One has to recall that during the first wave (1850-1914), globalisation was imposed on the rest of the world either by gunboat diplomacy or through colonial

\footnotetext{
${ }^{48}$ Editorial, 'A fat lot of good', Financial Times, 26 January 2006.
} 
Table 1. Similarities and differences between the two big globalisation waves

\begin{tabular}{|c|c|c|}
\hline Feature & First Wave 1850-1914 & Second Wave 1980-2008(?) \\
\hline $\begin{array}{l}\text { Technological revolu- } \\
\text { tion in transport and } \\
\text { communication }\end{array}$ & $\begin{array}{l}\text { Steamships, railways, telegraph and the opening of the Suez } \\
\text { Canal in } 1869 \text { (halved the distance from English to India's } \\
\text { ports). Laying down of the transatlantic telegraph cable } \\
\text { (1866). Fall in transport and communication costs. }\end{array}$ & $\begin{array}{l}\text { Container transport; mass air transport; relatively widespread, cheap and } \\
\text { reliable telephone services; and the Internet. Fall in transport and com- } \\
\text { munication costs. }\end{array}$ \\
\hline $\begin{array}{l}\text { Production: fragmenta- } \\
\text { tion, unbundling, off- } \\
\text { shoring or vertical } \\
\text { specialisation }\end{array}$ & $\begin{array}{l}\text { Technology primarily affected industries and firms. This per- } \\
\text { mitted spatial separation (unbundling) between the location of } \\
\text { production and the place of consumption of goods. } \\
\text { Productivity increased. }\end{array}$ & $\begin{array}{l}\text { Technological changes affected industries, firms, plant, sub-firm and } \\
\text { sub-plant levels. The location of all functionally related production } \\
\text { stages of one production process in a plant does not need to be located in } \\
\text { the geographical proximity (unbundling). Various stages of the same } \\
\text { production process and value chain can be fragmented and located in dif- } \\
\text { ferent places. There is trade in specific tasks. } \\
\text { Productivity increased. }\end{array}$ \\
\hline Sectors affected & Manufacturing & Manufacturing and tradable services \\
\hline Trade & $\begin{array}{l}\text { Inter-industry trade (primarily for manufactured goods). } \\
\text { Strong and different comparative advantages and a decline in } \\
\text { transport costs made large-scale trade possible. }\end{array}$ & $\begin{array}{l}\text { Intra-industry, intra-firm trade important. Cheap transport permits trade } \\
\text { as soon as there is a new product or a change in tastes even if the coun- } \\
\text { tries are comparable. }\end{array}$ \\
\hline Tariffs & High but transparent. & Low \\
\hline FDI & $\begin{array}{l}\text { Mainly from Britain. Half of FDI stock was in developing } \\
\text { countries, the other half in Canada, Europe and the US. }\end{array}$ & $\begin{array}{l}\text { Principally among the developed and newly industrialised countries. } \\
\text { Enormous amounts in absolute terms. } \\
\text { Developing countries are in general marginalised as locations for FDI. } \\
\text { The rise of China and Russia as destinations and sources of FDI from } \\
\text { 1990s. }\end{array}$ \\
\hline $\begin{array}{l}\text { Geographical spread of } \\
\text { production by means of } \\
\text { globalisation }\end{array}$ & Uneven & $\begin{array}{l}\text { Uneven, but principally towards South-East Asia. A strong Asian face of } \\
\text { globalisation. }\end{array}$ \\
\hline Industrialisation & $\begin{array}{l}\text { Europe and North America industrialised while Asia (China } \\
\text { and India) de-industrialised. Colonial masters prevented a } \\
\text { spread of new technology to colonies. }\end{array}$ & $\begin{array}{l}\text { Europe and North America de-industrialised while Asia industrialised. } \\
\text { Relatively faster international spread of new technology. }\end{array}$ \\
\hline Standardisation & Informal & Formal \\
\hline $\begin{array}{l}\text { Financial intermediar- } \\
\text { ies }\end{array}$ & Banks & $\begin{array}{l}\text { A variety of intermediaries: banks and institutional investors (pension } \\
\text { funds, mutual funds). }\end{array}$ \\
\hline
\end{tabular}


Table 1. Similarities and differences between the two big globalisation waves(Continued)

\begin{tabular}{|c|c|c|}
\hline Migration of people & $\begin{array}{l}\text { Generally liberal to the Americas and Australia. Some } \\
40 \text { million Europeans left Europe. }\end{array}$ & $\begin{array}{l}\text { Highly controlled and restricted. Destinations: oil rich Arab countries, the US, } \\
\text { Canada, Australia and Europe. }\end{array}$ \\
\hline $\begin{array}{l}\text { Institutional arrange- } \\
\text { ments }\end{array}$ & $\begin{array}{l}\text { Abolition of the Corn Laws in Britain (1846) and unilat- } \\
\text { eral British moves to free trade. } \\
\text { Largely informal supported and promoted by gunboat } \\
\text { diplomacy. } \\
\text { Based in many cases on colonial ties. }\end{array}$ & $\begin{array}{l}\text { Economic liberalisation, partly formal through international economic institu- } \\
\text { tions, partly informal through the economic strength and behaviour of TNCs. }\end{array}$ \\
\hline Urbanisation & Important & Important \\
\hline $\begin{array}{l}\text { Who are the winners } \\
\text { and losers from oppor- } \\
\text { tunities and risks } \\
\text { brought by globalisa- } \\
\text { tion? }\end{array}$ & $\begin{array}{l}\text { Some (elite) gained in both developing and developed } \\
\text { world. Many lost in both developed and developing } \\
\text { world (at least in the medium term). } \\
\text { Firms: Gainers are large, competitive, technology lead- } \\
\text { ers, risk-lovers, internationally mobile. Losers include } \\
\text { local, small and risk-averse firms. } \\
\text { Persons: Gainers are the educated, risk-lovers, those } \\
\text { who work in the 'winning' firms, mobile and asset own- } \\
\text { ers. } \\
\text { Losers include those who do not participate in globalisa- } \\
\text { tion, i.e. poorly and semi-educated, immobile, risk- } \\
\text { averse and wage earners in the uncompetitive firms and } \\
\text { industries. }\end{array}$ & $\begin{array}{l}\text { Hard to predict with certainty because of the fragmented production process } \\
\text { and value chain often within the same firm (or plant). Certain individuals } \\
\text { within a firm may gain, while others within the same firm may lose. Some } \\
\text { (elite) gained in both developing and developed world. Many lost in both the } \\
\text { developed and developing world (at least in the medium term). } \\
\text { Firms: Gainers are large, technology leaders, risk-lovers, internationally } \\
\text { mobile. Losers include local, small and risk-averse firms. } \\
\text { Persons: Gainers are the educated, some risk-lovers, mobile and mobile asset } \\
\text { owners. Losers include those who do not participate in globalisation, i.e. poorly } \\
\text { and semi-educated, immobile, risk-averse, wage earners particularly in certain } \\
\text { countries with highly regulated labour markets. }\end{array}$ \\
\hline $\begin{array}{l}\text { Public concern and } \\
\text { debate }\end{array}$ & Principally within the Communist party. & $\begin{array}{l}\text { Social impact and issues brought by globalisation are highly controversial and } \\
\text { fiercely debated: human rights, fair trade, labour laws, environment, NGOs,... } \\
\text { American social contract was broken: people and firms were free to succeed } \\
\text { and fail without assistance, but enormous sums of public money that went to } \\
\text { failed corporations changed that. }\end{array}$ \\
\hline $\begin{array}{l}\text { Deglobalisation ten- } \\
\text { dencies }\end{array}$ & Wars; First World War & $\begin{array}{l}\text { Asian financial crises (1997) } \\
\text { America-created global credit crunch (2007-08) and a shift of banking business } \\
\text { to home markets which banks know best and the expectation that the domestic } \\
\text { taxpayers would bail them out if a need arises } \\
\text { 'Buy domestic' and other indirect protectionist campaigns (2009) } \\
\text { 'Green' protectionism (environmental standards are used as NTBs) } \\
\text { Volatile (increasing) price of oil that increase transport and trade costs, as well } \\
\text { as insecurity for FDI } \\
\text { Quest for secure energy sources } \\
\text { Energy crises }\end{array}$ \\
\hline
\end{tabular}


control: China signed a trade treaty with Britain in 1842; Britain imposed 'free trade' on India, while the Dutch did the same with Indonesia during the 1840s; American gunboats forced Japan to open to trade in 1858; British gunboat diplomacy opened up most Latin American countries for trade somewhat earlier. [The] 'West practised protection wherever necessary, but imposed free trade on the Third World' (Nayyar, 2006, p. 139). The second wave (from 1960s) was principally based on advances in technology.

Opening of markets and creation of stronger trade and production linkages between the 'Old' and 'New' World took centuries. However, the speed of the establishment of similar ties increased over time. It took only a couple of short decades to establish similar linkages with China. Table 1 provides a list of suggestions about the basic economic features of the two big waves of globalisation. (For simplicity we limit our discussion here to only two waves. Many other waves may be identified depending on the purpose of analysis: technology, banking, politics, and so on). Both waves were supported by technological revolutions that included the fragmentation (unbundling) of the production process and value chain, transport and communication. The first one involved steamships, railways, telegraph and the opening of the Suez Canal. The second one includes container transport, mass air transport, cheap and reliable telephone services and the Internet.

The second big wave of globalisation brought important novelties. Hence the two big waves have certain differences:

- During the first wave, technology primarily affected industries and firms. This permitted spatial separation (unbundling) between the location of production and the place of consumption of goods. The second wave of globalisation brought an additional possibility for fragmentation of production: certain operations within the same factory can be unbundled and performed elsewhere. There is trade in specific tasks. Some services also became tradable.

- Tariffs were much higher during the first than is the case during the second globalisation wave.

- Non-tariff barriers (NTBs) are higher now than was the case during the first wave.

- The first wave included inter-industry trade (primary commodities for manufactured ones). During the second wave, an increasing share of trade is intraindustry (France both sells and buys cars from Germany). Intra-firm trade is highly important during the second wave. 
- FDI flowed to the developing countries during the first globalisation wave, but now the principal FDI flows are among the developed countries. There are noted flows from the developing to the developed world and to other developing countries.

- The first wave of globalisation involved huge migrations of people. Such migrations are now closely controlled and restricted.

- The second globalisation wave has a strong Asian dimension.

- There are difficulties in predicting winners and losers during the second wave. This wave introduced swift business reactions. Jobs that seemed to be 'safe' some three years ago may go abroad. Bank computer programming may migrate, for instance, from Europe to India or Russia. ${ }^{49}$

- There is a 'high resolution' impact on jobs during the second wave: some tasks or jobs in a firm/factory may be affected by globalisation, while others in the same firm/factory may not be influenced (yet).

- Liberal and mercantilist policy effects during the second wave: 'Suppose that home nation forbids outsourcing of data-entry jobs in an attempt to "save jobs". If other nations allow their firms to offshore, the home nation firms will find themselves at a competitive disadvantage. The expected result from this would be a reduction in home firm's production, so in the end the policy could end up indirectly "destroying" even more data-entry jobs rather than offshoring would "destroy" directly" (Baldwin, 2009, p. 18).

The spirit of globalisation might remain the same in both globalisation waves, but there are important space-related differences in their actual attainment. During the first wave the north (Europe and the US) industrialised, while the South (especially China and India) deindustrialised. There was an expansion of trade and factor movements (both labour and capital), while incomes between the two regions diverged. In the second wave of globalisation, it was the South (East Asia) that industrialised, while the North deindustrialised. Trade and capital mobility expanded (mass labour migration was small by the first-wave standards), while incomes between the two regions generally converged. Urbanisation remained an important feature in both North and South during both waves of globalisation (Baldwin and Martin, 2004, pp. 2707-8).

There is at least an alternative view about the globalisation waves, different from the one set out in Table 1. The characteristics of a number of economies in the preindustrial era was a relatively low and rather similar economic activity, high

${ }^{49}$ On this issue, see Marin (2011). 
costs of transports and relatively little trade. The three great eras of globalisation, according to Friedman (2006), contributed to the flattening of the world and gave certain arguments to the 'death of distance'.

The 'flat world' school of thought argues that there are rapidly diminishing differences, greater homogeneity and more equality among various geographical locations for production. Based on comparative advantages, state-led globalisation 1.0 (1492-1800) shrank the world from a size large to a size medium; based on internalisation of business within TNCs, TNC-led globalisation 2.0 (1800-2000) shrank it from medium to small; while individual-led globalisation 3.0 from around 2000 'is shrinking the world from a size small to a size tiny and flattening the playing field at the same time' (Friedman, 2006, p. 10).

Globalisation 3.0 is based on the unrealistic assumption that global trade is free and costless. There is neither theoretical nor practical support for such a stance. Hence, according to this view, geographical distance is neither a prevailing feature of the world economy nor an important economic barrier (this has a certain rationale for information technology, but extrapolation across the manufacturing and services board is inappropriate). A flat and shrinking geographical space (weightless economy) is preferred and necessary for the mathematical modelling of the economy and spatial location of firms and industries by those analysts who are searching for the solution within equilibrium.

The actual shape of the world is not flat and spatial distance still plays a role for the location of production and trade, although perhaps not as much as it used to in the past. Since the First Industrial Revolution (1750-1850) the costs of transport had, in general, a downward-sloping trend. Policy makers have been slowly dismantling certain policy barriers (tariffs, quotas) that facilitated and simplified trade and contributed to the flattening of the world. However, certain other policy barriers (NTBs) proliferated. This, together with an increasing complexity of goods and services, as well as an understanding of the complicated information is keeping and making the world somewhat big and rugged. Spatial distance is alive and in rather good health.

Globalisation brings certain economic and other opportunities, but it also brings a number of risks and perils. Globalisation is a double-edged sword. Some gained from it, many others lost and suffered. Usually, the few big, technology leaders, educated, internationally mobile and successful risk-lovers gained a lot. Others were generally on the losing side in the medium term. In any case, globalisation was a mixed blessing for developing countries. Free global markets are a superb 
and efficient instrument for wiping out fragile infant industries.

Globalisation may be a system that provides real opportunities to some to take the best out of the open global market economy and leave the rest to all others. As such, this type of elite globalisation may create and accentuate various economic and social asymmetries. Nayyar (2006, p. 158) commented:

Globalisation has introduced a new dimension to the exclusion of people from development. Exclusion is no longer simply about the inability to satisfy basic human needs in terms of food, clothing, shelter, health care and education for large numbers of people. It is much more complicated. For the consumption patterns and lifestyles of the rich associated with globalisation have powerful demonstration effects. People everywhere, even the poor and the excluded, are exposed to these consumption possibility frontiers because the electronic media has spread the consumerist message far and wide. This creates both expectations and aspirations. But the simple fact of life is that those who do not have the income cannot buy goods and services in the market. Thus, when the paradise of consumerism is unattainable, which is the case for common people, it only creates frustration or alienation. The reaction of people who experience such exclusion differs. Some seek short cuts to the consumerist paradise through drugs, crime or violence. Some seek refuge in ethnic identities, cultural chauvinism or religious fundamentalism. Such assertion of traditional or indigenous values is often the only thing that poor people can assert, for it brings an identity and meaning to their lives. Outcomes do not always take these extreme forms. But globalisation inevitably tends to erode social stability. Thus, economic integration with the world outside may accentuate social tensions or provoke social fragmentation within countries.

An enlarged market is an important gain for efficiency-seeking firms in a small country. In a situation without integration, foreign countries can simply threaten a small country that they will introduce protectionist measures or sanctions against it (the US frequently makes such threats to many countries). Such a warning can seriously undermine the quality of all economic decisions in a small country. Integration not only enhances and secures market access for partner countries, but it also increases the potential for long-term competitiveness of a small country's goods and services. A common market may eliminate or harmonise national incentives to foreign TNCs to locate in partner countries (which were previously subject to countervailing duties). It also mitigates non-economic considerations, 
such as political pressures on third-country investors to locate in a particular country.

\section{Corporate Social Responsibility}

One strand of the debate about globalisation, instigated by the political left, is where do social responsibilities of firms begin and where do they end? This is based on the increasing income inequalities resulting from liberalisation and globalisation, as well as social problems linked with such developments, and the inability or unwillingness of the state to ameliorate them. Hence, there is an attempt to involve the private sector in the solution of these social problems.

In order to increase local embeddedness and demonstrate corporate social responsibility (business ethics, even philanthropy), some TNCs involve themselves in local communities through sponsorship of local sporting and cultural events, education and training, health (HIV/AIDS) campaigns, even blood donations (by the local staff, of course).

Corporations such as Coca-Cola, McDonald's, Motorola or Nike publish annual reports on social responsibility. Some may argue that this is linked with a form of free advertisement as local media record such events. One needs to recall the situation during the First Industrial Revolution in Britain when industrialists who modernised factories lobbied in the early 1800s for the introduction of labour laws that curbed child labour. A noble social goal, no doubt. In essence, this was done to gain further competitive advantages over older and smaller plants that employed children. Pressing for the social responsibility agenda, the incumbent firms may, in effect, turn this into a cost-increasing measure, a business entry barrier for potential new entrants into the market. The social responsibility agenda ought to be socially and business friendly, not 'business owned'.

Cemex of Mexico, for example, is involved in a wide range of community development projects around the world: in the Philippines it supports educational initiatives for children, in Costa Rica it offers scholarships, while in Egypt it assists education of girls (UNCTAD, 2006, p. 233). Whether this is a calculated public relations ploy (as in the case of some Japanese and German TNCs that operate in Britain) to avoid criticism or a real and deep commitment towards the local communities remains unanswered (Dicken et al., 1995, p. 41).

Self-interest often plays a role in business ethics. A day-care facility by a firm for the children of its employees may assist the education of children or the 
reduction in teenage crime. Good and responsible deeds towards the local community, no doubt. However, the real and underlying reason for this action and financial investment may be the firm's wish to reduce the absenteeism of its employees and to reduce the costs that come from the resulting lower production.

In any case, TNCs endeavour to present themselves as good corporate citizens who are socially and environmentally responsible, bringing benefits to the local community and the host country. None the less, rational firms, in principle, do not normally invest funds in being ethical or 'green' unless they expect to obtain something in return from the general business environment For instance, they expect, more clients or easier taxation from the government or both from such socially responsible actions. In addition, there is a general social dilemma regarding firms that produce cigarettes, alcohol or arms that also wish to be socially responsible.

The Global Compact, launched by the UN in 2000, is a large voluntary corporate citizenship initiative. By 2009 it had grown to involve 6,700 participants, of which 5,200 are from the business community. They adhere to 10 principles that cover issues such as human rights, labour standards, environment and business ethics. These 10 principles are:

\section{Human rights}

1. Protection of internationally accepted human rights.

2. No involvement in human rights abuses.

\section{Labour standards}

3. Respect of freedom of association and collective bargaining.

4. Elimination of forced and compulsory labour.

5. Abolition of child labour.

6. Removal of discrimination regarding occupation and employment.

\section{Environment}

7. Environmental challenges should be dealt with on the basis of the precautionary principle.

8. Promotion of a greater environmental responsibility.

9. Creation and widespread employment of environmentally friendly technologies ought to be encouraged.

\section{Anti-corruption}

10. Participants (and others) should work against all types and forms of 
corruption..$^{50}$

These principles stem from the idea that corporations have to consider the impact of their operations on all stakeholders. The general inspiration has roots in the anti-capitalist movement since the 1970s. It is also linked to the Nestlé infant formula marketing case. Nestlé promoted infant formula over breast milk in the poor developing countries. Samples of formula were given for free when the mothers and children were in maternity wards. Once they left them, the formula was no longer free. Parents had to buy the formula and to prepare it with water, which was, in certain cases, found to be contaminated. Sometimes they used more water than necessary to make the formula last longer. This led to malnutrition, diseases, suffering and, in certain cases, infant mortality. Under the umbrella of 'humanitarian aid', a TNC could create markets. This provoked fury in 1977 against Nestlé in the US, which also spread to Europe.

Globalisation may have a favourable social impact on the environment if 'clean' foreign firms replace environment-unfriendly domestic ones. If a TNC from country A (with higher environmental standards than elsewhere) fears that it can be sued at home for environmental damage done in country B, then this TNC would promulgate globally high environment-related standards.

The widest 'international community' endorses the 10 Global Compact principles. The stakeholders include the business community, labour organisations and NGOs such as Transparency International and Amnesty International, as well as international organisations. The problem is still the global application of these principles on the ground, both by developed- and developing-country players. Critics of the Global Compact argue (i) that there are no efficient screening and enforcement tools to ensure that TNCs actually adhere to the principles, and that there are no mechanisms to sanction member TNCs for non-compliance; (ii) that participation in the Compact does not depend on the actual behaviour of the TNC; and (iii) that the Global Compact may be a public relations ploy to improve the image of the participating TNCs ('bluewash'). Hence, the anti-globalisation movement has a new area of concern.

\footnotetext{
${ }^{50}$ This is particularly important in the resource-rich developing countries. It is often alleged that their rulers siphon off a sizeable part of receipts from TNCs that are in the extraction business to their private accounts. The domestic population receives very little from the exploitation of the national wealth in resources.
} 


\section{Other Globalisation Strands}

Transnational corporations behave like other firms: primarily they follow the opportunities for maximising profit while staying within the law. The most prominent motivators for their transborder business operations include the size and growth of the local market. These are supplemented by the privileged access to international markets (instead of mere differences in the cost of labour or in taxation) and possibilities for vertical integration of the fragmented value chain. In a situation where market liberalisation has become a widely accepted policy choice, there is an increase in the importance of created assets and structures (technology and the ability to create it, business culture, and the capability to organise and control production and marketing, communications infrastructure, and marketing networks) as determinants for the attraction and location of FDI. This is why 84 per cent of the activities of TNCs were located in developed-market economies (measured by the inward stock of FDI in 2008) (UNCTAD, 2009, p. 251). In spite of the talk about 'globalisation', on average, a significant part of the output of affiliates is still sold, as noted earlier, on the local market. In this situation, the developing countries and those in transition face very tough competition to attract TNCs.

Foreign investors will locate their activities in a country that offers the most favourable cost mix of operation (production and marketing), provided that this factors well into the longer-term vision of potential profit making. FDI can be made simpler by regionalisation of the world economy and international economic integration. However, integration/regionalisation is only a supporting tool for the tendencies that bring about international business globalisation. Modern competitive firms are usually TNCs that 'globalise' their fragmented business process in the search for seamless and extensive markets. Therefore, an increasing share of domestic output, even in developed countries, is under the control of foreign TNCs. The same holds for an increasing share of foreign output of domestic TNCs. Strong FDI relations may exist even though the countries or groups of countries are not formally integrated. Just look at the example of twoway FDI flows between the US and the EU; or China where this country both receives FDI in manufacturing and, at the same time, it invests abroad (for instance, in the development of resources and energy in Africa or in hightechnology firms in the US).

Some observe and fear that the ongoing global and large-scale reallocation of 
manufacturing towards China is damaging for other national economies. Let us recall what Williams (1896, pp. 10-11) ${ }^{51}$ wrote more than a century ago:

A gigantic commercial State is arising to menace our prosperity, and contend with us for the trade of the world. Take observations, Gentle Reader, in your own surroundings. You will find that the material of some of your own clothes was probably woven in Germany. Still more probable is it that some of your wife's garments are German importations. The toys, and the dolls, and the fairy books which your children maltreat in the nursery are made in Germany. Roam the house over, and the fateful mark will greet you at every turn, blazoned though it be with the legend, 'Made in Germany.'

Does such a story and tone sound familiar nowadays? Of course, if we replace Germany with China. Are such concerns well founded?

A part of the answer may be found by searching for the location where the big money is made in the global economy. For instance, the price of an iPod in the US was $\$ 299$ in 2008 . Out of that final price, only $\$ 4$ stays in China with the assembler. The biggest chunk of the final price, $\$ 160$, goes to American firms that design, transport and market iPods. ${ }^{52}$ Or, out of each cup of coffee that Americans drink, less than 3 per cent of the price goes to Latin American coffee growers, while the remaining 97 per cent goes to those who were processing, branding, marketing or otherwise involved in other knowledge-based activities that ended up in a cup of coffee. Most of these 'extras' are based outside Latin America. ${ }^{53}$ Or, the cost of production in Indonesia and shipping of a pair of Nike basketball shoes was $\$ 16$, while the sales price of the same pair was $\$ 70$ in America (Cohen, 2006, pp. 56-57). Thus the big money lies with those in the global economy who tell 'others' what to make.

The new, Asian face of globalisation, may not please many in the US and Europe. As recently as 2006, the Indian entrepreneur Lakshmi Mittal took over Arcelor, Europe's largest steel maker; the US barred the Chinese takeover of Unocal, an oil company (China may be a source of cheap clothes and toys, but to own an American oil company is another story) ${ }^{54}$ During 2006 there was also a

\footnotetext{
${ }^{51}$ Quoted from Combes et al. (2008), p. 88.

${ }^{52}$ The Economist, 'Winners and losers', 28 February 2008.

${ }^{53}$ A. Oppenheimer, 'Latin America is lagging', Washington Post, 13 January 2008.

${ }^{54}$ 'Back in the early stages of the financial crises, wags joked that our trade with China had turned out to be fair and balanced after all: They sold us poison toys and tainted seafood; we sold them fraudulent securities' (P. Krugman, 'China's dollar trap', New York Times, 3 April 2009).
} 
wave of economic 'patriotism' in the EU. France and Spain protected their domestic energy market from takeovers even from the companies of fellow EU member countries. The same is true for banking in Italy and Poland. Will the Russians in the new global world own and control a large chunk of the EU gas distribution services, or increase their 5 per cent share in the European Aeronautic Defence and Space Company (EADS) which not only owns Airbus, but is also active in the aerospace and defence business? China owns 10\% in Blackstone, the world's largest private equity firm that has a stake in 43 industrial groups including energy, pharmaceuticals and Deutsche Telecom. ${ }^{55}$ Has the West lost control over globalisation? Once a fashionable and positive word, globalisation has become something that has a negative connotation which makes many people leery in both the rich and poor worlds. Can the West rein in forces that it proudly unleashed and profited from for decades? Is globalisation justified only when it serves the interest of the Western world? Many Asian countries are now appealing to the Western world not to abandon free trade.

The relation between social spending and the competitiveness of a country's goods and services in a global economy is complex. There is no set of golden (global) rules and examples to be followed at all times. Since the 1980s, a high-tax welfare state in Sweden has proven to be quite successful in the economy, as is the lower-tax and less-regulated British economy. Some argue that TNCs rush to locate in countries with low social spending to save on costs. However, de Grauwe and Polan (2003) found evidence that wealthy countries that spend most on social needs, on average rank highest in terms of competitiveness. Countries with highly competitive output generate extra income. They can afford generous social outlays. But there is also a reverse causality. Competitiveness depends on an absence of prolonged social conflicts, superb human capital and the quality of the government. People would be prone to risk taking if they knew that they would not be condemned to poverty if they fail. One of the principal roles of an efficient government is to transform social security contributions into energy for social value added. Those that manage this conversion well are likely to benefit in terms of enhanced competitiveness and welfare.

The glue that binds trans-Atlantic relations together is not principally trade, but FDI. Large global interpenetration of FDI reduces the possibility that regional arrangements may become closed blocs. A 'hostage population' of TNCs may

\footnotetext{
${ }^{55}$ 'State foreign investments: the EU considers its response', Bulletin Quotidien Europe, 24 July 2007, p. 3.
} 
reduce the fear of retaliatory measures. Extensive FDI links between the US and the EU have helped to reduce potential conflict between the two partners relating to market access. The same is not yet true of Japan and China. It is hoped that Japan will mature as a foreign investor in the future and that potential conflict with that country will be defused. As far as China is concerned, this country may increase its FDI in the US and perhaps Europe also in the future, in addition to expanding investments in the development of resources in Africa, Latin America and Asia.

Relatively open economies and liberal rules for investment and capital movements have assisted Western firms to penetrate new countries and markets for decades. This helped the prosperity of the Western world. However, Western countries, in particular the US, are being (partly/slowly) replaced by China and India as engines of world economic growth. Many manufacturing and certain services jobs are going to Asia. Brazil and Russia are also economic giants in the making.

The introduction of monetary union in the EU in 1999, including the euro as a subregional currency, replaced national moneys for 12 countries. Expectations about the beneficial economic impact of the monetary union among the EU elite were high. However, the growth rate in the eurozone countries is low, unemployment is high and countries have serious and continuous difficulties in sticking to the budgetary rules. The European Constitution failed in 2005. The message from the voters to the politicians at that time may be put in the following simple words: 'Do not embark on other grand (global) projects unless and until you fix the current ones.'

The objective of sovereign wealth funds is to preserve (national) wealth (UNCTAD, 2008, pp. 20-26). Some of them have been in existence since the 1950s. These funds started as government 'investment vehicles' that recycle a huge inflow of dollars. They are managed separately from the official foreign exchange reserves of the country. The best known are the ones that originate in the oil exporting countries such as Kuwait, the United Arab Emirates, Saudi Arabia, Libya, Norway and Russia. In addition, China and Singapore also have sovereign wealth funds of their own. There are 44 countries with such funds, together disposing of some $\$ 5$ trillion. About three-quarters of FDI from these funds are concentrated mainly in the United Kingdom, the US and Germany.

Sovereign wealth funds are directly controlled by the home-country government, they may withstand both higher risks and for a longer period of time than a purely 
commercial financial institution can, and they may merge economic and noneconomic logic in their investment policy. With the exception of the Norwegian, ${ }^{56}$ Canadian and Kuwaiti sovereign wealth funds, they do not reveal their investment decisions or asset portfolios. They have little legal responsibility to shareholders, voters or regulators. The IMF, the OECD and the European Commission have plans to develop voluntary principles for the operation of sovereign wealth funds.

There is a concern by both developed and developing countries that sovereign wealth funds may acquire ownership and/or control of strategic national assets such as transport infrastructure, and supply and distribution of energy. To counter this potential threat, the US has the Exxon-Florio Amendment (1988) which gave the US president the right to block mergers, acquisitions or takeovers of domestic firms by foreign investors when such action is likely to jeopardise national security. ${ }^{57}$ Other countries have similar restrictions. None the less, there is no evidence so far that the sovereign wealth funds tried to wield undue influence on firms in which they invest. Perhaps they may do that in the future, but until then, they deserve the benefit of the doubt. Because of their long-term investment stance, the 'genetic code' of sovereign wealth funds understands that the world and its economy is not based on the zero-sum game (short-term scarcity mentality), but rather on the abundance mentality in which everyone may gain in the long term. Time will show if genetic modifications and mutations will take place in these 'business genes'.

\section{Conclusions}

Globalisation was supposed to be one of the grand ideas in the "post-modern society'. Has it been so? Is it just a red herring? Does globalisation make sense? Is it taking us for a ride? The answer depends on what you mean by 'globalisation'. As there is no generally accepted or standardised definition of globalisation, the term means different things to different people. Hence, this may introduce confusion in discussions and analysis. If globalisation is principally the process driven by the behaviour of TNCs that also influence the policies of governments (the slant taken in this chapter), then globalisation is still rather limited mostly to the developed countries and the newly emerging economies. Many countries in the

\footnotetext{
${ }^{56}$ During the global credit crunch the Norwegian sovereign wealth fund lost $€ 75$ billion in 2008 (R. Anderson, 'Norway reviews $€ 75$ bn loss in wealth fund', Financial Times, 3 April 2009).

${ }^{57}$ Greenfield investments are not subject to this Amendment.
} 
world are strongly touched by globalisation, but sizeable parts of the world population are still not affected obviously and positively by this process. Globalisation tries to expand and impose its standards on new areas. When globalisation expanded into new areas, it often encountered a palpable and stubborn resistance. This was because of the perception that it may not bring obvious benefits to the locals and because it may harm the local culture, damage the environment and have a negative impact on income distribution. Globalisation is also fragile. Unexpected events such as a volcano eruption in Iceland created havoc in transport and business in Europe for over a week in April 2010. Earlier, the global credit crunch (2007-08) significantly reduced trade, FDI and contributed to 'buy domestic' campaigns.

Adam Smith and David Hume taught us that all countries grow together in the longer term (not at each other's expense). This ought to be always kept in mind. Benefits of globalisation as measured by the spread of FDI, economic growth and development, were much less global and equal than the neoclassical partisans of globalisation argued and expected.

As globalisation allegedly flattened the world by reducing distances (in financial, communication and organisational terms), some may accept and argue that spatial location of production no longer matters too much for players in the national and international economy. Transport and other trade costs are reduced, hence the actual location of production matters less than was the case earlier. This is an illusion. By making firms more footloose, globalisation makes them sensitive to small differences that prevail in various locations. Because of a high mobility of TNCs, a small initial difference in a footloose world may have a profound longerterm impact on location and clustering of mobile economic activity. Physical distance and geographical location still matter for the location of economic activity even in a 'globalised' and footloose world, as the efficient use of technology often depends on the accumulated local talents and experiences (Jovanović, 2009).

New technologies permitted the fragmentation of the production process. This allowed the global geographical spread of business activities. However, if a firm wants to be strong globally, it must first be strong locally. In a 'globalised' world, local advantages may become more, not less important. The examples of corporations such as Microsoft, Benetton and pharmaceutical TNCs in Basle clearly prove this argument.

The new actors in the globalisation process (China, India, Brazil and Russia) profit from the unleashed spirit of globalisation. They change the perception of the 
substance of this process in the countries that initially allowed globalisation to run free. Once the newcomers start to profit from globalisation, there follows a wave of domestic patriotism (read protectionism) in the developed-market economies. The cases in question include the US resistance to the foreign takeover of eastern ports by Dubai Ports World in 2006 or the takeover of Unocal (domestic American oil producer) by the China National Offshore Oil Corporation (CNOOC) in 2005. ${ }^{58}$ Conversely, the Chinese rejected Coca Cola's bid to buy a Chinese juice maker in a controversial anti-monopoly ruling in 2009. In the EU there are worries about an expansion of Russian FDI even though the assets remain in the EU. At the same time, Russia has been asked to open up its domestic strategic (resources) market for the European FDI which may influence the development, volume and dynamics of energy production in Russia. ${ }^{59}$

Corporations have strongly increased their power in contemporary society through widespread lobbying of governments and international organisations (WTO), as well as through privatisation. The authority of the state (and various social groups) has diminished over many dimensions of business affairs of TNCs. Consequently, there are fears about undemocratic concentration of power and the rule of the wealthy (in order to make even more wealth for themselves). In this situation, the distribution of income and wealth benefited the already rich (owners of capital) to the detriment of the poor and the weak. Globalisation was not supposed to work like that. This has introduced serious questions regarding the credentials of the democratic processes and outcomes in the free market and liberal (democratic) countries. There is a spreading absenteeism from the electoral process and certain direct confrontations between the people and powerful TNCs, their associations and various economic summits. None the less, public authorities are

\footnotetext{
${ }^{58}$ The alleged threat to the American interests was that the Chinese might divert some or all of Unocal's energy supplies to meet Chinese needs. This threat to US interests may be grounded if sources of supply are tightly concentrated and linked with high switching costs. Unocal's production of energy of 'threetenths of 1 percent of US use' could easily be replaced by American buyers 'with extra imports, leaving net imports and the US balance of payments in energy unchanged' (Moran, 2009, pp. 1-2). Another example of a similar national security policy case in the US can be found in the Bain-Huawei (China) offer to buy 3Com (2007). While Huawei was the largest maker of network equipment in China, 3Com was a small player in the US. The two firms had a joint venture and already knew each other well. Even though the Chinese wanted to buy a minority stake in $3 \mathrm{Com}$, the US authorities did not clear the deal.

${ }^{59}$ 'In 2006, when Lakshmi Mittal bid for Arcelor, a European steel firm, he met fierce and seemingly racist opposition from the governments of France, Luxembourg and Spain, which preferred to see their champion merge with a Russian rival rather than with "a company of Indians", as Arcelor's chairman put it. The deal went ahead only when India's government threatened a trade war' (The Economist, 'Oil, politics and corruption', 18 September 2008).
} 
not powerless. Civil society and society in general demand and get protection from wild (liberal) global markets where 'everything is permitted'. Therefore, states legislate and reorganise from within in the light of globalisation. As corporate globalisation may bring many useful amenities to society, the idea is to come to a social (even international) agreement on what kind of globalisation is desirable. In addition, there ought to be an accord on how to achieve this objective. State authorities ought to step in, reinvigorate the democratic process and regulate (a code of conduct) on national and international levels where and to the extent that it is appropriate.

Received 3 February 2010, Revised 12 July 2010, Accepted 27 July 2010

\section{References}

Ahearne, A., J. Pisani-Ferry, A. Sapir and N. Veron (2006), “The EU and the Governance of Globalisation", Prime Minister's Office, Economic Council of Finland.

Baldwin, R. (2009), "Integration of the North American Economy and New-Paradigm globalisation", CEPR Discussion Paper, No. 7523.

Baldwin, R. and P. Martin (2004), “Agglomeration and Regional Growth', in Handbook of Regional and Urban Economics (eds J. Henderson and J. Thisse), Amsterdam: Elsevier, pp. 2671-2711.

Brakman, S., H. Garretsen and C. van Marrewijk (2009), The New Introduction to Geographical Economics, Cambridge: Cambridge University Press.

Cohen, D. (2006), Globalisation and Its Enemies, Cambridge MA: The MIT Press.

Combes, P., T. Mayer and J. Thisse (2008), Economic Geography, Princeton: Princeton University Press.

de Grauwe, P. and M. Polan (2003), "Globalisation and Social Spending", CESifo Working Paper, No. 885, Munich.

Dicken, P., M. Forsgren and A. Malmberg (1995), "The Local Embeddedness of Transnational Corporations" in Globalization, Institutions and Regional Development in Europe (eds A. Amin and N. Thrift), Oxford: Oxford University Press, pp. 23-45.

Evola, J. (1934), Rivolta Contro il Mondo Moderno [Revolt Against the Modern World]. Milano: Ulrico Hoepli.

Ethier, W. (2011), "Contemporary Regionalism", in International Handbook on the Economics of Integration Vol. I (ed. M. Jovanović), Cheltenham: Edward Elgar (forthcoming).

Fiorentino, R. (2011), "The Never Ending Story of Regional Trade Agreements", in International Handbook on the Economics of Integration Vol. I (ed. M. Jovanović), Cheltenham: Edward Elgar (forthcoming). 
Fratianni, M., and F. Marchionne (2011), "The Limits to Integration", in International Handbook on the Economics of Integration Vol. I (ed. M. Jovanović), Cheltenham: Edward Elgar (forthcoming).

Friedman, T. (2006), The World is Flat, New York: Farrar, Straus \& Giroux.

Hufbauer, G. and J. Schott (2009), "Buy American: Bad for Jobs, Worse for Reputation" Policy Brief, Paterson Institute for International Economics, Washington DC.

Hummels, D. (2006), "Transportation Costs and Trade over Time", in Transport and International Trade, OECD: Paris, pp. 7-26.

Ietto-Gillies, G. (2003), "The role of Transnational Corporations in the Globalisation Process", in the Handbook of Globalisation (ed. J. Michie), Cheltenham: Edward Elgar, pp. 139-149.

Ietto-Gillies, G. (2005), Transnational Corporations and International Production, Cheltenham: Edward Elgar.

Jovanović, M. (2006), The Economics of International Integration, Cheltenham: Edward Elgar.

Jovanović, M. (2009), Evolutionary Economic Geography, London: Routledge.

Kalaji ć, D. (1979), Smak Sveta [Doomsday], Zagreb: Nakladni Zavod Matice Hrvatske. Kim, H. (2008), 'Location choices of Korean MNEs in East Asia: Escaping the Nutcracker' in Economic Integration in East Asia (eds. M. Fujita, S. Kumagai and K. Nishkimi), Cheltenham: Edward Elgar, pp. 203-248.

Lipsey, R.G. (1992), An Introduction to Positive Economics, London: Weidenfeld and Nicolson.

Lipsey, R.G. (2004), "Some Plusses and Minuses of globalisation”, Simon Fraser University, Burnaby, BC, Department of Economics, mimeo.

Lipsey, R. (2011), “Technology and Globalisation”, in International Handbook on the Economics of Integration Vol. I. (ed. M.Jovanović) Cheltenham: Edward Elgar (forthcoming).

Lipsey, R.G., K. Carlaw and C. Bekar (2005), Economic Transformations: General Purpose Technologies and Long Term Economic Growth, Oxford: Oxford University Press.

Lovering, J. (2006), "The New Imperial Geography", in Economic Geography (eds S. Bagchi-sen and H. Lawton Smith), London: Routledge, pp. 221-232.

Marin, D. (2011), "The Opening up of Eastern Europe at 20: jobs, skills, and reverse maquiladoras in Austria and Germany", in International Handbook on the Economics of Integration Vol. II (ed. M. Jovanović), Cheltenham: Edward Elgar (forthcoming).

McGrew, A. (1992), "Conceptualizing Global Politics", in Global Politics (A. McGrew and P. Lewis, eds), Cambridge: Polity Press, pp. 1-28.

Michie, J. (ed.)(2003), The Handbook of Globalisation, Cheltenham: Edward Elgar.

Moran, T. (2009), "Three Threats: an Analytical framework for the CFIUS Process", Paterson Institute for International Economics, In Brief, August 2009.

Nayyar, D. (2006), "Globalisation, History and Development: a Tale of Two Centuries", Cambridge Journal of Economics, pp.137-159. 
OECD (2007), OECD Economic Surveys: European Union. Paris: OECD.

OECD (2010), Globalisation, Transport and the Environment, Paris: OECD.

O'Rurke, K. and J. Williamson (2000), Globalization and History. Cambridge: The MIT Press.

Porter, M. (1994), "The Role of Location in Competition", Journal of the Economics of Business, pp. 35-39.

Romer, P. (2010), "Which Parts of Globalisation Matter for Catch-up Growth?", NBER Working Paper, No. 15755, Cambridge, MA.

Rugman, A. (2002), "Multinational Enterprise and the end of Global Strategy", in Multinational Firms: The Global-Local Dilemma (eds J. Dunning and J. Mucchielli), London: Routledge, pp. 3-17.

Rugman, A. and R. Hodgetts (2001), "The End of Global Strategy", European Management Journal, pp. 333-343.

Rugman, A. and C. Oh (2008), "Friedman's Follies: Insights on the Globalization/ Regionalization Debate", Business and Politics, Issue 2, article 4, pp.1-14.

Rugman, A., and C. Oh (2011), "Multinational Enterprises and Regional Economic Integration: Rethinking Key Metrics in International Business", in International Handbook on the Economics of Integration Vol. III (ed. M. Jovanović), Cheltenham: Edward Elgar (forthcoming).

Scholte, J. (2008), "Defining globalisation", The World Economy, pp. 1471-1502.

Steger, M. (2009), Globalization, Oxford: Oxford University Press.

Stiglitz, J. (2002), Globalization and Its Discontents, London: Allen Lane.

Strange, S. (2003), "An International Political Economy Perspective", in Governments, Globalization, and International Business (ed. J. Dunning), Oxford: Oxford University Press, pp. 132-145.

UNCTAD (1993), World Investment Report: Transnational Corporations and Integrated International Production, New York: United Nations.

UNCTAD (2006), World Investment Report: FDI from Developing and Transition Economies, United Nations: New York.

UNCTAD (2008), World Investment Report: Transnational Corporations and the Infrastructure Challenge, United Nations: New York.

UNCTAD (2009), World Investment Report: Transnational Corporations, Agricultural Production and Development, United Nations: New York.

Williams, E. (1896), Made in Germany, London: William Heinemann.

Wolf, M. (2004). 'Globalization and Global Economic Governance', Oxford Review of Economic Policy, pp. 72-84.

Wolf, M. (2005), “Will Globalization Survive?", Third Whitman Lecture, Washington: Institute for International Economics.

World Bank (2009), World Development Report: Reshaping Economic Geography, Washington: The World Bank. 